\title{
Museum Leadership in Practice: A New Zealand Case Study.
}

\author{
By \\ David Luoni
}

A dissertation submitted in partial fulfilment of the requirements for the degree of Master of Museum and Heritage Studies to the Victoria University of Wellington, New Zealand. 

Table of Contents

\begin{tabular}{|l|l|l|}
\hline Abstract & & 1 \\
\hline $\begin{array}{l}\text { Introductory Chapter } \\
\text { and Literature Review }\end{array}$ & $\begin{array}{l}\text { Introduction } \\
\text { Leadership Research within Museum } \\
\text { Studies } \\
\text { Wider Leadership Research } \\
\text { Research Design }\end{array}$ & $\begin{array}{l}3-5 \\
\text { Geddes' career path }\end{array}$ \\
\hline Chapter One & $\begin{array}{l}6-14 \\
14-18\end{array}$ \\
\hline Chapter Two & Leadership Interviews & $19-32$ \\
\hline Chapter Three & Comparing Theory and Practice & $33-48$ \\
\hline Conclusion & Leadership as a cultural practice & $62-65$ \\
\hline Bibliography & & $66-69$ \\
\hline
\end{tabular}




\begin{abstract}
Museum leadership is an under investigated area of museum studies. This dissertation contributes to museum leadership research by applying leadership theory to a case study of the career of Jim Geddes, a museum director who works in the town of Gore in Southland, New Zealand. In 2008 Geddes won Museums Aotearoa's inaugural Individual Achievement Award for putting Gore on the national cultural map by establishing the Eastern Southland Gallery, the Hokonui Heritage Centre, the Croydon Aviation Museum and for expanding Gore's Historical Museum. How did Geddes achieve this successful cultural entrepreneurship in such an unlikely small rural town?
\end{abstract}

The central research question asks how leadership has manifested itself in Gore's museums during Geddes' tenure from 1983 to the present. The theoretical framework draws on leadership theory, particularly the work of Suchy and others, who theorise leadership as a social practice rather than a set of management techniques. Several qualitative research methods are employed including interviews with Geddes and key museum stakeholders coupled with a review of how the media have presented Geddes' work. This research data is then compared against leadership theory, noting the convergences and divergences. The dissertation is the first in-depth New Zealand study to test the application of contemporary leadership theory to one museum leader's practice. The findings reveal that, while Geddes is not a conscious leader, his practice has a striking similarity to the engaging transformational leadership model in terms of stakeholder engagement and the interpersonal and emotional elements of leadership.

This research provides a deeper understanding of the career of a successful local museum director, suggesting that a sense of place can function as a mechanism for museum leaders to profitably engage with stakeholders. It also presents the argument that successful leadership is a practice, a mode of operating and interacting with others that if consistently applied can spark a series of positive events for museums and their leaders. After considering the implications of this case study for museum practice, training and professional development, the dissertation concludes with five recommendations to improve museum leadership development in New Zealand. 


\section{Introduction}

'Go for broke and start from nothing, find an opportunity or community will and hijack it' ${ }^{1}$

Here in a nutshell is Jim Geddes' approach to museum leadership. It is a philosophy that has served him and his community well. In 2008, while working as, Gore's District Curator, Geddes won Museums Aotearoa's inaugural Individual Achievement Award for establishing several museums that have put his hometown on the national cultural map. How did Geddes achieve this successful cultural entrepreneurship in such an unlikely setting? Despite his reputation, Geddes claims he does not understand leadership and that he is not a conscious leader. This dissertation explores this elusive concept of leadership, within a museum context. It is a response to limited New Zealand research on museum leadership and applies international leadership theory to a case study of Geddes' twenty eight year museum career in Gore. ${ }^{2}$ My research question asks how has leadership manifested itself in Gore's Museums during Geddes' tenure from 1983 to the present.

My research field is Museum and Heritage Studies which involves the analysis of the history, theory and practice of museums, art galleries, and of cultural and natural heritage. This dissertation is concerned with the sub field of museum leadership theory and practice, particularly the intersections between theory and practice. By conducting original research on this topic, it is hoped this study will contribute to Museum Studies and related fields in New Zealand as the first local case study to test the application of international leadership theory to one director's practice. Associated contributions are a review of leadership theory and a record of Geddes' career. The research will provide insights into how Geddes has successfully engaged with his community to develop its cultural life and facilities. I also intend to consider the implications of the research findings for the wider issue of museum leadership development in New Zealand. In the following section, I review the relevant literature by looking first at museum studies' scholarship on museum leadership and I then consider general leadership theory to establish a wider theoretical framework through which to analyse Geddes' leadership practices.

\footnotetext{
${ }^{1}$ Jim Geddes, interview, October 6, 2011.

${ }^{2}$ Gore is a rural service town with a population of approximately 10,000 in the province of Southland.

The town's district is Eastern Southland (Hokonui in Māori).
} 


\section{Literature review}

\section{Research within Museum Studies}

In the field of museum studies, there are a several texts on museum management which address leadership as well as a few general anthologies in which museum director's reflect on their experience. For example, Genoways and Ireland note the multifaceted role of a museum director, referring to thirteen texts on effective museum leadership and tabulate the key leadership characteristics identified in these texts. ${ }^{3}$ One of the more recent texts on museum management and leadership is the 2007 anthology entitled Museum Management and Marketing. ${ }^{4}$ In their introductory essay the editors Sandell and Janes distinguish between management and leadership, describing 'management as coping with complexity and leadership as coping with change'. They conclude that fundamentally leadership requires keeping people moving ahead' 5 In chapter 16, Stuart Davies notes the vast literature devoted to leadership and adopts a simple definition of leadership: 'Leadership is the process in which an individual influences other group members toward the attainment of group or organisational goals'. ${ }^{6}$ Referring to Kotter, Davies suggests that the key roles of a leader are to: 'establish direction, align people, motivate, inspire and changing outcomes'. 7 Davies also refers to the evolution of leadership theory and identifies several separate ways to identify leadership: by trait, by contingency theory ${ }^{8}$ and by attribution theory ${ }^{9}$. He notes that the research has moved from focusing solely on the qualities that leaders are expected to display towards a more rounded view which includes the environmental factors that influence leadership. ${ }^{10}$ Davies relates the results of research carried out by the University of East Anglia's Museum Leadership

\footnotetext{
${ }^{3}$ Hugh H. Genoways and Lynne M. Ireland, Museum Administration: an introduction (Lanham: Altamira Press, 2003), 333.

${ }^{4}$ Richard Sandell and Robert R. Janes, eds., Museum Management and Marketing, Leicester Reader in Museum Studies (Oxford: Routledge, 2007).

${ }^{5}$ Richard Sandell and Robert Janes, "Complexity and Creativity in Museum Management and Marketing," in Museum Management and Marketing, ed. Richard Sandell and Robert Janes, Leicester Reader in Museum Studies (Oxford: Routledge, 2007), 5.

${ }^{6}$ S.W Davies, "Visionary Leadership and Missionary Zeal," in Museum Management and Marketing, ed. Richard Sandell and Robert R. Janes, Leicester Reader in Museum Studies (Oxford: Routledge, 2007), 254.

${ }^{7}$ ibid citing J.P Kotter. The Leadership Factor, London: Collier Macmillan 1990.

${ }^{8}$ By contingencies of situation, group nature and composition.

${ }^{9}$ Observing the behaviour of leaders and followers and attributing causes to that behaviour.

${ }^{10}$ Davies, "Visionary Leadership and Missionary Zeal," 256.
} 
Programme which identified the following overall museum leadership characteristics, (in order of priority):

Produces a clear vision and focuses activities on achieving it. Ensures adequate funding. Is able to communicate. Has professional credibility. Establishes policies, goals and strategies. Understands strategic issues. ${ }^{11}$

Davies concludes that the museum leader emerges as a strategy, stakeholder and contingency manager. ${ }^{12}$ Standing back, it seems to me that Davies concentrates more on managerial considerations and gives considerably less focus to the behavioural and emotional elements of leadership.

In 1998, Sherene Suchy completed an international study of the director's role in art museum leadership for her doctorate thesis. ${ }^{13}$ She interviewed seventy two international art museum directors and professionals specialising in museum leadership development programmes, executive-selection as well as government representatives and specialists in the not for profit sector. Suchy concluded that an art museum leader's role is fourfold:

1. 'To represent the museum's story to external/internal audiences guided by personal passion.

2. To create contexts where others (staff and volunteers) can give their best to each other and to visitors.

3. To act as ethical entrepreneurs assessing and shaping opportunities into viable economic outcomes to ensure the museum's future.

4. To nurture relationships of trust with key stakeholders around the museum for long term sustainability. ${ }^{14}$

The requisite skills and attributes that emerged out of Suchy's research were:

- Emotional intelligence: the ability to deal with emotions, to perceive, understand and manage them in a way that serves the individual and the relationships around them. ${ }^{15}$

- Intentionality: acting on purpose and accepting responsibility for one's actions.

- Creativity: tapping non-cognitive resources to envision new ideas.

\footnotetext{
${ }^{11}$ Ibid, 264.

12 Ibid, 270.

${ }^{13}$ Sherene Suchy, “An international study on the director's role in art museum leadership" (Doctorate Thesis, University of Western Sydney, 1998), http://arrow.uws.edu.au:8080/vital/access/manager/Repository/uws:517.

${ }^{14}$ Sherene Suchy, Leading with Passion: Change Management in the 21 st-century Museum (California: Altamira Press, 2004), xviii.

${ }^{15}$ Ibid, 35.
} 
- Intuition: using a higher reasoning; tuning into non-cognitive cues.

- Compassion: appreciating and honouring others' feelings and points of view; forgiveness.

- Interpersonal connection: creating and sustaining a network of supportive people.

- Constructive discontent: handling conflicts in a creative and empowering way.

- $\quad$ Resilience: using rest and renewal to build energy, overcome obstacles and maintain hope.

- Trust radius: trusting others until there is reason not to. ${ }^{16}$

Suchy's research puts a heavy emphasis on the emotional aspects of leadership. She also identifies passion and flow theory as guiding principles. Suchy equates passion with 'energy and heart ${ }^{\prime 17}$ and describes being 'in flow' as when challenges are paced with an individual's growth in capacity over time. ${ }^{18}$ Suchy's work has an authenticity born of in-depth sector specific research and I found her analysis of museum leadership to be the most cogent of the museum-specific research.

The most recent New Zealand research is an unpublished report on museum leadership development options prepared by the New Zealand Tourism Research Institute ${ }^{19}$ for National Services Te Paerangi. ${ }^{20}$ The researchers interviewed fifteen participants in New Zealand and international museum leadership development programmes. One of the report's key recommendations is that future museum leadership programmes focus on strategy, governance issues and leadership styles including behavioural-based personal development. The report then offers a series of recommendations on how this could be best achieved.

\footnotetext{
${ }^{16}$ Ibid, 37.

${ }^{17}$ Ibid, 29.

${ }^{18}$ Ibid, 32.

${ }^{19}$ At the Auckland University of Technology

${ }^{20}$ The department of the Museum of New Zealand Te Papa Tongarewa responsible for museum sector development and training.
} 


\section{Wider Leadership Research}

What does wider leadership research have to offer in terms of theoretical frameworks? At the very broadest level the research considers the characteristics of leaders, followers and situations. ${ }^{21}$ Viewed this way, the pattern that emerges out of the leadership literature is a widening consideration of, leaders, the relationship between leaders and followers, out to a consideration of leadership of a group operating within society. Yukl ${ }^{22}$ conceptualises leadership on four hierarchical levels. ${ }^{23}$ The first is intra-individual which looks at leaders' cognition, motivations and self -management. The second is dyadic: the analysis of leader and follower influence at an interpersonal level. Yukl's third level examines leadership as a group process and his fourth level analyses leadership as an organisational process within a larger open system (in which groups are subsystems). Professors Brad Jackson and Ken Parry break the myriad of leadership theories down to five manageable groupings: leader-centred, followercentred, cultural, critical and higher purpose perspectives on leadership. ${ }^{24}$ This provides a helpful framework on which to outline the main theories.

Leader centred leadership theories

Trait theory was an early analysis of leadership and dates back to the 1920 and 1930s. It was concerned with the innate qualities of recognised leaders with traits such as honesty, intelligence, competency, the ability to plan and inspire. Trait theory has been largely superseded because it did not go on and consider the behavioural, influence and situational elements of leadership. Since the 1940s, style theorists have paid closer attention to effective leadership behaviour. Pioneering work at the Universities of Ohio State and Michigan during the 1950s has evolved into detailed assessments of task, relations and change-orientated behaviours. Yukl has helpfully tabulated these types of behaviours. ${ }^{25}$

\footnotetext{
${ }^{21}$ Gary A. Yukl, Leadership in Organizations, 6th ed. (New Jersey: Pearson, Prentice Hall, 2006), 12.

${ }^{22}$ Dr Gary Yukl is a Professor of management at the University of Albany, New York and a preeminent leadership academic.

${ }^{23}$ Yukl, Leadership in Organizations, 15-17.

${ }^{24}$ Brad Jackson and Ken W. Parry, A Very Short, Fairly Interesting and Reasonably Cheap Book about Studying Leadership (London: SAGE Publications Limited, 2008).

${ }^{25}$ Yukl, Leadership in Organizations, 66-67 .
} 
In the 1980s a new paradigm emerged called transformational leadership, which quickly gained traction. It emerged out of (and in good part as a reaction against) transactional theory, which is concerned with how goals can be achieved by appeals to self-interest. Transformational leadership integrates wider motivations. Bernard Bass' original formulation identified three types of transformational behaviour: idealised influence, intellectual stimulation and individualised consideration. ${ }^{26}$ Transformational leadership seeks to engender trust, admiration, loyalty and respect in relationships and thereby generate motivation. Transformational leaders also 'articulate a vision and realise strategies ${ }^{, 27}$ and have been described as 'managers of meaning' and 'sense makers'. ${ }^{28}$ In the late 1990s, Bass, Avolio and Jung theorised that effective leadership modelled both transactional and transformative behaviours and developed a Multifactor Leadership Questionnaire (MLQ) ${ }^{29}$ which measures a broad range of leadership from (in order of effectiveness): transforming, rewarding, correcting and avoiding. The questionnaire has three versions, a self, a team and an organisational rating. Programmes for the selection and training of leaders based on the MLQ are frequently used by the human resource industry. In broad terms the MLQ measures:

\begin{tabular}{|l|l|}
\hline \multicolumn{2}{|c|}{ Table One: Multifactor Leadership } \\
\hline Transformative leadership & $\begin{array}{l}\text { Developing a vision, engendering pride, respect and } \\
\text { trust, creating higher expectations, modelling } \\
\text { appropriate behaviour. }\end{array}$ \\
\hline Inspirational and visionary & $\begin{array}{l}\text { Continually challenging followers with new ideas and } \\
\text { approaches; using symbols to focus efforts. }\end{array}$ \\
\hline Intellectual stimulation & $\begin{array}{l}\text { Taking risks and giving personal attention to } \\
\text { followers, giving them respect and responsibility, } \\
\text { developing them. }\end{array}$ \\
\hline $\begin{array}{l}\text { Individualised consideration } \\
\text { and development exchange }\end{array}$ & $\begin{array}{l}\text { Rewarding followers for conformity with performance } \\
\text { targets. }\end{array}$ \\
\hline Transactional leadership & $\begin{array}{l}\text { Looking for mistakes or exceptions to expected } \\
\text { behaviour and then taking corrective action. }\end{array}$ \\
\hline Contingent reward & $\begin{array}{l}\text { Waiting for mistakes to happen before intervening, } \\
\text { abdicating leadership responsibility. }\end{array}$ \\
\hline $\begin{array}{l}\text { Passive or avoidant managemanagement by } \\
\text { exception }\end{array}$ \\
\hline $\begin{array}{l}\text { Passive management by } \\
\text { exception }\end{array}$
\end{tabular}

\footnotetext{
${ }^{26}$ Bernard M. Bass, Leadership and performance beyond expectations (Free Press, 1985).

${ }^{27}$ Jackson and Parry, A Very Short, Fairly Interesting and Reasonably Cheap Book about Studying Leadership, 28

${ }^{28}$ Ibid.

${ }^{29}$ B.J. Avolio, B.M. Bass, and D.I. Jung, "Re-examining the components of transformational and transactional leadership using the multifactor leadership questionnaire," Journal of Occupational and Organisational Psychology, no. 72 (1999): 441-62.
} 
In the late 1990s Alimo-Metcalfe's and Alban-Metcalfe's research concluded that engagement underpins transformative leadership and posited that effective leaders engage ethical values, individuals, the organisation and stakeholders. The values and behaviours that drive each dimension are summarised in the following diagram and are also assessed in a widely used questionnaire. ${ }^{30}$

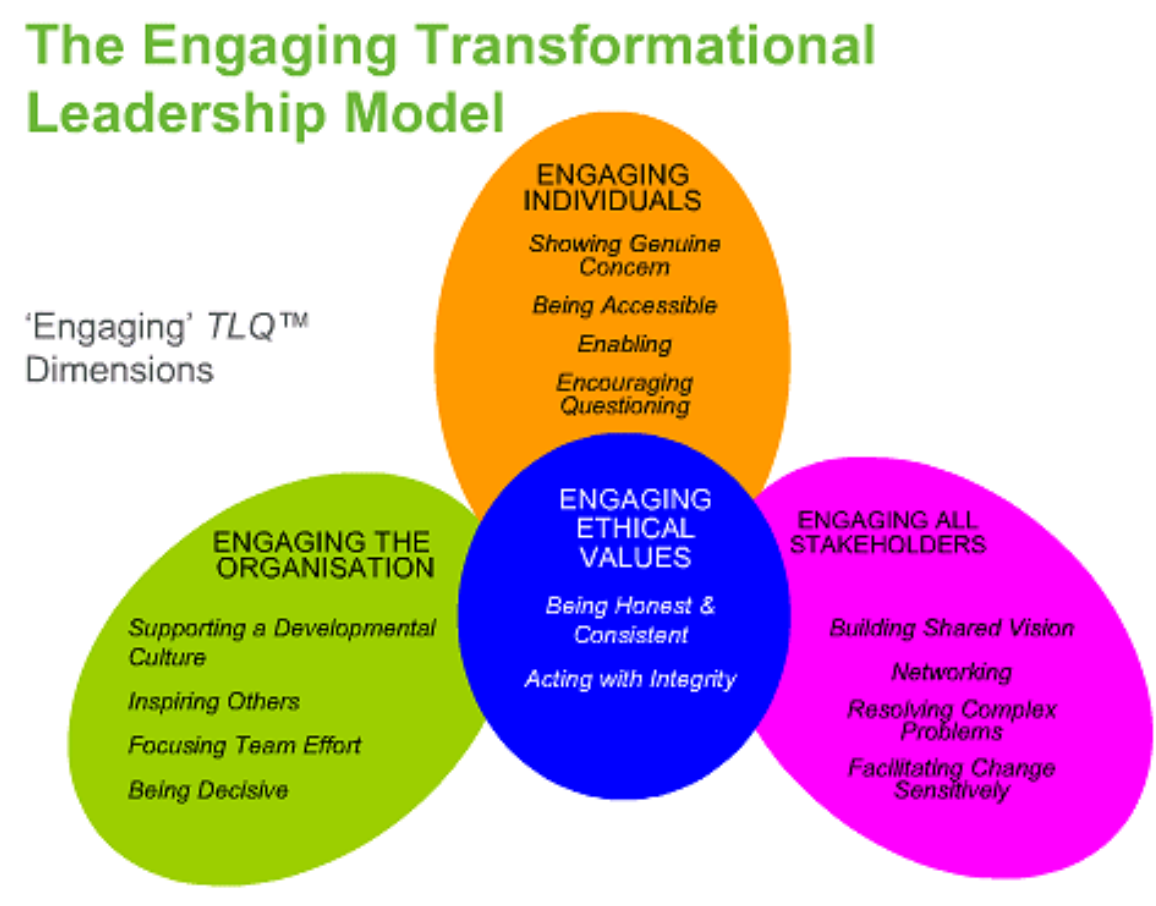

${ }^{31}$ The Engaging Transformational Leadership Model TM

In a recent presentation, Professor Alimo-Metcalfe sets out an insightful view of the challenge of leadership, namely to:

Deliver the highest quality of services with fewer resources, while doing no harm. To develop potential, commitment and relationships and to create cultures that build capacity and ensure sustainability. ${ }^{32}$

The TLQ model is compelling because it is conceptually broad enough to reference and include all four of Yukl's conceptual levels, it can accommodate differing levels of leadership and has a behavioural focus. Suchy's model is remarkably similar to the

\footnotetext{
${ }^{30}$ The 'Engaging Transformational Leadership Questionnaire' (TLQ).

${ }^{31}$ Beverly Alimo-Metcalfe, "Leadership, culture and transformation: building capacity across communities" (presented at the NE Leading Improvement for Health and Well-being Programme: Learning event 2, Durham University, April 16, 2010), 12, http://www.dur.ac.uk/resources/public.health/nelihwp/NELIHWBPLE2BevAlimoMetcalfe.pdf.

32 Alimo-Metcalfe, "Leadership, culture and transformation: building capacity across communities."
} 
TLQ model but I found the latter to be more refined and capable of multi-sector application.

Follower-centred leadership theories

Joseph Rost offers an aspirational definition of leadership as an: 'influence relationship among leaders and followers who intend real changes that reflect their mutual purposes'. ${ }^{33}$ Jackson and Parry agree that genuine leadership requires multidirectional leadership where followers are active partners and that a change is the result of a common purpose rather than coercion. ${ }^{34}$ A pithy overview of recent follower-centred perspectives on leadership is found in a series by the same name. ${ }^{35}$ In his introduction, Shamir identifies various roles that followers play in leadership theories, namely: recipients of leaders' influence, moderators of leaders' impact, constructors of leadership, substitutes for leadership and followers as leaders ${ }^{36}$ and coproducers of leadership. ${ }^{37}$ Shamir assesses these perspectives as tools to:

Reverse the lens of leadership... and look at how followers contribute to the construction of leadership, how they empower the leader, influence the leader's behaviour and what is their contribution to determining the consequence of the leadership relationship'. ${ }^{38}$

Cultural and Critical Perspectives on Leadership

Cultural theory examines how context influences leadership at an organisational level both in terms of cross-cultural leadership and the implications of globalisation. One line of research that caught my attention in Jackson and Parry's overview was Andrew Jones' analysis of 'cultural theory of leadership'. ${ }^{39}$ Jones studied organisational leadership at the intersection between local culture and larger cultural and economic forces. His research focused on three 'American South' companies. Jones' concluded that one of the leaders' key roles was to be protectors of 'southern culture' or 'keepers of the tribe'. Jones concluded that leaders can derive their

\footnotetext{
${ }^{33}$ Joseph Clarence Rost, Leadership for the twenty-first century (Westport, Connecticut: Greenwood Publishing Group, 1993), 102.

${ }^{34}$ Jackson and Parry, A Very Short, Fairly Interesting and Reasonably Cheap Book about Studying Leadership, 15.

${ }^{35}$ Boas Shamir et al., eds., Follower-centered perspectives on leadership: a tribute to the memory of James R. Meindl, Leadership Horizons (United States of America: Information Age Publishing, Inc, 2007).

${ }^{36}$ Ibid, ix.

${ }^{37}$ Ibid, xix.

${ }^{38}$ Ibid, xxi.

${ }^{39}$ Jackson and Parry, A Very Short, Fairly Interesting and Reasonably Cheap Book about Studying Leadership, 79.
} 
leadership legitimacy and power from being local and global at the same time. ${ }^{40}$ What interests me here, is whether Geddes derives a degree of legitimacy from being local and national at the same time. Jones' work introduces a sense of place and of belonging to that place, as elements of leadership, which are useful to my study.

Critical theory challenges the predominant view that leaders are people in charge and followers are the people influenced. Critical theorists make the claim that leadership is a process that goes on between all people and that all people can be involved in leadership in spite of their formal position. ${ }^{41}$ The theories under this head are: coleadership, distributed leadership, leaderless workgroups and team leadership and are sometimes grouped under the banner of post heroic modes of leadership.

\section{Leadership with a Higher Purpose}

This area of research examines the ethical, moral and spiritual aspects of leadership. This is sometimes expressed as 'Authentic Leadership', which strives to be moral and aims for universal rather than divisive values. It is an extension of transformational leadership theory and is encapsulated in the hub of the TLQ model. Authentic leaders are not motivated by retaining power, they persuade by the merit and relevance of their ideas for the followers' ultimate benefit and focus on the best in people. ${ }^{42}$

Authenticity is signalled by trust, integrity and high moral standards, all of which are central to Suchy's and the TLQ models of leadership. In their commentary on leadership with a higher purpose, Jackson and Parry refer to the spirituality of leadership, noting research into leadership elements such as: self-awareness, emotion, passion, the management of meaning, intrinsic motivation, wisdom, discernment, courage, transcendence and interconnectedness. ${ }^{43}$ Fry's theory of spiritual leadership is an intrinsic motivation model that incorporates the elements in the following table: ${ }^{44}$

\footnotetext{
${ }^{40}$ A.M. Jones, "The Anthropology of Leadership: Culture and Corporate Leadership in the American South," Leadership 9, no. 1 (2005): 259-278.

${ }^{41}$ Jackson and Parry, A Very Short, Fairly Interesting and Reasonably Cheap Book about Studying Leadership, 83.

${ }^{42}$ Ibid, 98-99.

${ }^{43}$ Ibid, 101.

${ }^{44}$ L.W Fry, "Toward a paradigm of spiritual leadership," Leadership Quarterly 15, no. 5 (2006): 619722 .
} 
Table Two: Elements of Spiritual Leadership

\begin{tabular}{|l|l|l|}
\hline \multicolumn{1}{|c|}{ Vision } & \multicolumn{1}{c|}{ Altruism } & \multicolumn{1}{c|}{ Hope/faith } \\
\hline $\begin{array}{l}\text { Broad appeal to } \\
\text { stakeholders }\end{array}$ & Trust/loyalty & Endurance \\
\hline $\begin{array}{l}\text { Defines the destination } \\
\text { and journey }\end{array}$ & $\begin{array}{l}\text { Acceptance/gratitude and } \\
\text { forgiveness }\end{array}$ & Perseverance \\
\hline Reflects high ideals & Integrity/honesty/courage & Does what it takes \\
\hline Encourages hope & Humility/kindness/compassion & Stretches goals \\
\hline $\begin{array}{l}\text { Establishes standards of } \\
\text { excellence }\end{array}$ & Patience & $\begin{array}{l}\text { Expectation of } \\
\text { reward/victory }\end{array}$ \\
\hline & & Excellence \\
\hline
\end{tabular}

This table is from Mario Fernando's, Spiritual Leadership in the Entrepreneurial Business. ${ }^{4}$

These principles align with those espoused by Greenleaf's servant leadership theory which advances: listening, empathy, healing, awareness, persuasion, conceptualising, foresight, stewardship, growth and building community as the keys to acquiring authority. ${ }^{46}$ Greenleaf says that true leadership 'emerges from those whose primary motivation is a deep desire to help others' ${ }^{47}$

\section{Recent theory}

One of the more recent theories to be published is Whitney, Trosten-Bloom, and Rader's adoption of Appreciative Inquiry as a leadership model. ${ }^{48}$ Appreciative Inquiry seeks to discover the positive qualities and capabilities of an organisation and use them as a basis for change rather than focusing on what is wrong and then trying to fix it. The authors define Appreciative Leadership as 'the relational capacity to mobilize creative potential and turn it into positive power; to set in motion positive ripples of confidence, energy, enthusiasm and performance' ${ }^{49}$ They set out five core mobilising strategies: Inquiry, Illumination, Inclusion, Inspiration, and Integrity ${ }^{50}$ which overlap with many of the criteria in the other leadership models.

\footnotetext{
${ }^{45}$ Mario Fernando, Spiritual leadership in the entrepreneurial business: a multifaith study (Edward Elgar Publishing, 2007), 30.

${ }^{46}$ Robert K. Greenleaf et al., The servant-leader within: a transformative path (Paulist Press, 2003), 16-19.

${ }^{47}$ Ibid, 15.

${ }^{48}$ Diana Whitney, Amanda Trosten-Bloom, and Kae Rader, Appreciative Leadership: Focus on What Works to Drive Winning Performance and Build a Thriving Organization (McGraw-Hill Professional, 2010).

${ }^{49}$ Ibid, 3.

${ }^{50}$ Ibid, 23.
} 
The final theory that I consider in this review is complexity theory as it applies to leadership. Blandin cites a number of leadership scholars who recognise a disconnection between the reality of today's social systems and conventional leadership theory. ${ }^{51}$ She takes the view that leadership theory has not kept pace with more highly complex and dynamic organisations. Blandin opines that so many of the current leadership theories are based on transformational leadership theory and that it is the dominant leadership paradigm. ${ }^{52}$ She advances complexity theory as a new model which has its roots in the field of complexity science which refers to the 'dynamic behaviour of systems whose parts continually interact and reorganize themselves into more adaptive patterns over time'. ${ }^{53}$ Falconer states that it is a 'systemic state on the cusp between chaos and order, a condition where uncertainty, variety, dependency and interconnectedness are high. ${ }^{54}$

Complexity theory has been applied in the realm of physics, molecular chemistry, cellular growth and meteorology. So how does this translate to an analysis of leadership? The key analogy is to think of organisations as living systems with a large number of independent agents who, through dynamic interaction with each other, adapt and effect change. Pascale, Millemann and Gioja take the view that complex adaptive systems favour a decentralized structure. They say 'the self-organising potential of a system is enhanced by devolving power, establishing rich connections to form networks, and enriching those networks with information. ${ }^{55}$ Lewin and Regine's research concluded that 'leading in a dynamic system is more like an improvisational dance with a system rather than a mechanistic imperative of doing things to the system, as if it were an object that could be fixed'. ${ }^{56}$

Complexity scholars promote leadership as a catalyst, collaborator or facilitator role rather than using the notional view of a leader as being a person in charge, someone who controls, directs and motivates. ${ }^{57}$ Blandin observes that under this model leadership is created through 'interaction with others and is continually constructed' ${ }^{58}$

\footnotetext{
${ }^{51}$ Nanette Blandin, "Leading at the Edge of Chaos," in Transforming Public Leadership for the 21st Century, Transformative Trends in Governance and Democracy (New York: M.E. Sharpe, Inc, 2007), 138.

52 Ibid, 139.

${ }^{53}$ Richard T. Pascale, Mark Millemann, and Linda Gioja, Surfing the Edge of Chaos: The Laws of Nature and the New Laws of Business (Three Rivers Press, 2001), 127.

${ }^{54}$ James Falconer, “Accountability in a Complex World,” Emergence 4, no. 4 (2002): 28.

${ }^{55}$ Pascale, Millemann, and Gioja, Surfing the Edge of Chaos, 130.

${ }^{56}$ Roger Lewin and Birute Regine, The soul at work: listen, respond, let go : embracing complexity science for business success (Simon \& Schuster, 2000), 17.

${ }^{57}$ Blandin, "Leading at the Edge of Chaos," 147.

${ }^{58}$ Ibid.
} 
For me the crux of Blandin's work is her analysis of the key attributes of complexity based leadership, which Blandin summarised as follows:

- 'Process orientation: leaders still need to be concerned about results but their control over results is not always casual and is often non-linear. However they can have an enduring impact on how work is done.

- Zeal and persistence: these attributes are especially important in a volatile and highly competitive environment where passivity is not rewarded. This does not equate to aggressive, combative and noisy behaviour. Such leadership involves emotional maturity and intellectual versus personal ambition.

- Agility, resiliency and adaption: since things are always in flux, the ability to regroup, change direction, modify plans and adjust thinking are absolutely vital. Included in this is being comfortable with ambiguity and have a positive outlook on change and uncertainty.

- High level communication skills: effective communication in a complex system involves much more than effectively conveying information. Listening is an equally if not more important skill. So too are dialogue, inquiry and reflection.

- Boundary crossing/collaboration: leaders in complex organisations consider boundaries to be permeable membranes. One of the primary roles of those exercising leadership is to keep boundaries fluid, develop and sustain connections and promote collaboration.

- Commitment to diversity: diversity is central to a complex system's ability to adapt and to achieve higher levels of fitness. Diversity needs to be demonstrated, not only in terms of what is politically correct but in terms of truly valuing diverse perspectives and allowing them to be heard.

- Commitment to continuous learning: This attribute is so fundamental to a complex system that without it, it might cease to exist.

- Self-awareness/maturity/authenticity. Operating effectively within a complex system requires a high degree of emotional maturity. Individuals exercising such maturity exhibit: self-awareness, confidence, wisdom, intuition, a willingness to learn from others, admission of mistakes and the ability to see other perspectives and humility. ${ }^{59}$

Complexity theory offers another window through which to view leadership. I see its strengths as its emphasis on adaptability, the necessity for collaboration and the fact that it comfortably integrates all of Yukl's conceptual levels (primarily referencing

\footnotetext{
${ }^{59}$ Ibid, 148.
} 
itself in the fourth). Its emphasis on flexibility and a surrender of control (working at the edge of chaos) ${ }^{60}$ adds something new to the leadership literature. It seems to me that Blandin's attributes analysis complements Suchy's work, the transformative end of the MLQ model and the engagement aspect of the TLQ model. Complexity leadership theory puts a greater emphasis on diversity and adaption as the key drivers of successful leadership.

The literature on leadership theory surveyed above is rich and provides a framework for this study. However, it is clear that there are limited case studies comparing leadership theory and practice in the context of museums; this is especially so in New Zealand with only one such case study which focuses on one museum director's experience in activating community engagement. ${ }^{61}$ In this study, Professor Brad Jackson refers to the ways in which Tim Walker, then director of TheNewDowse in Lower Hutt, engaged with the local community. Overall however, despite useful work like this, and much valuable international theory, there is a lack of academic research on museum leadership in New Zealand today, despite the perception that there is a shortage of New Zealand museum directors. This literature review confirms that there is a place for further research along the lines proposed here and that this case study therefore has the potential to reveal useful insights into the exercise of leadership in the context of the small museum and heritage enterprises, which dominate the New Zealand sector.

\section{Research Design}

The central research question in this dissertation is: how has leadership manifested itself in Gore's Museums during Geddes' tenure from 1983 to the present? As stated above, the study will employ leadership theory from a range of disciplines to examine the practice of one successful museum director. My research design is a qualitative (single) case study of Geddes' career in Gore over nearly three decades. Case studies

\footnotetext{
${ }^{60}$ Elizabeth M. McMillan, Complexity, Organizations and Change (Routledge, 2004), 95. McMillan refers to three zones of a complex adaptive system: a stable zone, an unstable zone and a narrow transition zone between the two, 'the edge of chaos'. McMillan offers the view that an organisation balanced at the edge of chaos has 'sufficient freedom for creativity, entrepreneurship and risk taking to emerge. There is on-going change but there is a dynamic balance so that the organisation does not tip over into massive confusion and uncertainty'.

${ }^{61}$ Brad Jackson, "Getting Respect at the Dowse," in Communication and Organisations: Case Studies in New Zealand and Australia, ed. Theodore Zorn and Deborah Page (Auckland: Pearson Prentice Hall, 2007), 171-177.
} 
are ideal for holistic, in-depth investigation ${ }^{62}$ and have the advantage of drawing detail from the participants' perspective. Stake recommends a triangulated approach to case study data collection in order to increase the accuracy of research and to allow for a range of explanations to emerge. ${ }^{63}$ Stake outlines four protocols for triangulating case studies, namely: data ${ }^{64}$, investigator, ${ }^{65}$ theory, ${ }^{66}$ and methodological ${ }^{67}$ triangulation. ${ }^{68}$ I intend to use methodological and theoretical triangulation. The methodological triangulation uses three qualitative research techniques namely: interviews with Geddes and museum stakeholders, a review of media publications on Geddes' work and collaboration with Geddes to prepare a graphic presentation of his roles and stakeholder networks. The theoretical triangulation involves comparing Geddes's leadership practices to at least three separate leadership theories (as outlined in the literature review).

The interviews with Geddes and three other museum stakeholders will elicit their various thoughts, feelings and beliefs and allow for the participants to shape the concepts, terms and elements. This also helps minimise potential researcher bias. As Suchy observes, 'lived experience is the best form of authority'. ${ }^{69}$ A review of local and national articles will relate how the print media has interpreted and presented Geddes' work to the public. The articles will inevitably have varying degrees of reliability, but the advantage of examining public representations of Geddes' leadership outweighs any disadvantage.

The major criticism levelled at case studies is that they are too specific and the results are not widely applicable to other cases. Yin counters this by observing that case studies findings can be safely generalised to theoretical propositions (but not to populations). Yin also advocates what he terms 'analytic generalization', which involves comparing the empirical results of case studies to previously developed

\footnotetext{
${ }^{62}$ Joe R. Feagin, Anthony M. Orum, and Gideon Sjoberg, eds., A Case for the Case Study (Chapel Hill: The University of North Carolina Press, 1991), 6.

${ }^{63}$ Robert E. Stake, The Art of Case Study Research (Thousand Oaks, California: SAGE, 1995), 107121.

${ }^{64}$ Data source triangulation is where a researcher looks for the data to remain the same in different contexts.

${ }^{65}$ Investigator triangulation involves several investigators examining the same phenomenon.

${ }^{66}$ Theory triangulation involves the application of alternative theoretical viewpoints.

${ }^{67}$ Methodological triangulation occurs when one approach is followed by at least two others.

${ }^{68}$ Stake, The Art of Case Study Research, 110-114.

${ }^{69}$ Suchy, Leading with passion, 220.
} 
theory. ${ }^{70}$ My comparison of Geddes' practice against leadership theory adopts this approach. Stake counters the above criticism of case studies in a different way, relying on a more intuitive approach which he calls 'naturalistic generalization'. Stake reasons that where the data generated by case studies aligns with a reader's experiences and/or sense of logic this in itself facilitates a greater understanding of the phenomenon being researched. ${ }^{71}$

Yin's observation that single case studies are a valid way to confirm a theory or to represent a unique case ${ }^{72}$ applies to my research. So too does his point that single-case studies suit revelatory cases where an observer may have access to a phenomenon that was previously inaccessible. ${ }^{73}$ Having lived and worked in Gore for the past fifteen years and in my dual roles as a Museum and Heritage Studies student and as a Heritage Projects Officer employed by the Gore District Council, I am uniquely placed to undertake this case study.

The case study is based on five interviews with Geddes and interviews with representatives of three stakeholders to elicit community, funder and employee perspectives. My first two interviews with Geddes were structured as open interviews during which Geddes outlined his career path. The remaining three were semistructured interviews designed to draw out Geddes' leadership practices. These interviews inquired into Geddes' vision as District Curator as well as his professional successes, challenges and failures. I inquired into Geddes' professional motivations, his view of the role of a museum leader and the personal values/attributes he endeavours to bring to his work. I asked why Geddes has remained in Gore, what he sees as future leadership aspirations and challenges, as well as his advice for aspiring museum leaders. I then collaborated with Geddes' to prepare a role and network analysis in the form of a diagram. The first stakeholder interviewee was Mr Tracy Hicks, Mayor of the Gore District Council and current chair of the Community Trust of Southland. The Gore District Council is the territorial authority responsible for the delivery of Gore's cultural well-being under the Local Government Act 2002. Geddes heads the Council's Arts and Heritage Department. The interview with Mayor Hicks

\footnotetext{
${ }^{70}$ Robert K. Yin, Case study research: design and methods, vol. 5, Second. Applied Social Research Methods Series (Thousand Oaks, California: Sage Publications, 1994), 31-33.

${ }^{71}$ Stake, The Art of Case Study Research, 64.

${ }^{72}$ Yin, Case study research, 5:38.

${ }^{73}$ Ibid, 5:40.
} 
provides both a community and funders perspective. The second interviewee was $\mathrm{Mr}$ John Prendergast, the CEO of the Community Trust of Southland, a regional funding agency which annually makes grants totalling approximately $\$ 8$ million to $\$ 10$ million to Southland's not for profit sector. The Community Trust of Southland has been a major sponsor of all of Geddes' capital development projects. Prendergast has worked with Geddes on these projects for the past fourteen years. The third interviewee was Ms Stephanie Herring who works part-time in the Gore Museum in a fused collection management and research role. Herring's interview was designed to present an insider's perspective. I had also planned to interview the Auckland based print makers and gallery owners Frans Baetens and Magda van Gils who have donated their Voirin Press and other print making equipment to the Eastern Southland Gallery but regrettably they were unavailable.

All of the participants are experienced professionals and have made an informed decision to participate in the case study. In my view the main risk of the case study is that it could be intrusive on Geddes at both a professional and personal level and that an in depth analysis could be potentially embarrassing. The most realistic protection mechanism is to acknowledge the above risk at the outset and remain live to it throughout the research and analysis stages. I secured Geddes' informed consent at the outset and referred my findings to him for his comment before submitting the dissertation. I specifically sought and obtained Geddes' consent to included personal details such as the extent of his financial assistance to the museums in his Department. Another potential risk is researcher bias (given that I work in the Department and Geddes is my supervisor). I cannot eliminate this risk, but using multiple data sources and eliciting data direct from the participants and publications minimises this risk. Researching a supervisor's practice also presents risks if I draw any adverse conclusions and the risk is that I fail to do so in favour of expediency. Again I cannot eliminate this risk but I am aware of it. The Human Ethics Committee of Victoria University of Wellington approved my application to conduct this case study on 26 September 2011.

I conclude this Introduction by presenting a brief outline of the contents of the following three chapters. Chapter one provides an overview of Geddes' career and identifies the important junctures in his development as a leader, ending with a review 
of a range of media articles relating to his work. Chapter two relates the results of my semi-structured interviews with Geddes, Hicks, Prendergast and Herring. The third chapter is devoted to an analysis of the data by comparing it to the leadership theories identified in the literature review. I conclude with a summary of my findings and a discussion of the professional and academic implications of this study. 


\section{Chapter One}

\section{Geddes' Career Path}

\section{Introduction}

This dissertation presents a detailed case study of one museum leader. In order to situate Jim Geddes in his institutional and cultural context, and set the scene for the analysis which follows in chapters two and three, this chapter provides background information. It traces Geddes' career path and career milestones to provide a basis to assess his leadership practices. Career choice usually reveals a number of influences and this holds true in Geddes' case.

Jim Geddes grew up in Gore, attended the local High School (from 1972 to1975) and left at the end of sixth form, to attend a pre-entry fine arts course at the Southland Polytechnic. While there he volunteered at the Southland Museum and Art Gallery and enjoyed 'the multifaceted nature of it' ${ }^{1}$ An entry level role was an option but the then Director Russell Beck, encouraged Geddes to gain a tertiary qualification before taking up a full-time job in the museum sector. Geddes took Beck's advice and went on to art school in Dunedin graduating with a Diploma of Fine Arts in 1980.

Geddes majored in print making at art school but the Diploma course also included: art history, aesthetic studies, photography, sculpture and design. Despite training as an artist, Geddes never envisaged himself as a professional artist, "there were so few full time contemporary artists. In those days, the standard career path was to art galleries, television, design or work as an art teacher'. Geddes played in an art school band, 'organised gigs' and recalled 'almost taking time out to play music'. Instead he returned home to Southland and in 1981 and 1982 juggled three jobs as a barman, design work for a small advertising company and weekend work at the Southland Museum and Art Gallery. The 'high volume, commercial focus' of the advertising work did not appeal and Geddes opted to venture back into the music scene. Living back in Gore, he 'got a band together' and played professionally in Christchurch, Dunedin and Queenstown for eighteen or so months. The 'music thing helped financially' and he recalls 'a really diverse time, playing to some pretty rough

\footnotetext{
${ }^{1}$ Jim Geddes, September 19, 2011 (subsequent quotes are from this interview, until indicated otherwise).
} 
audiences'. At the time, Gore's taverns were reluctant to host bands, so in response, Geddes and several friends hired a local function centre once every second month and hosted bands from Dunedin's Flying Nun label. This catered for a younger market, which was not being served by the more conservative cultural scene offered by the local operatic, repertory, chamber music and historical societies. The sole visual arts event was part of an annual summer festival hosted by the local Lions club which included such diverse events as a rodeo, a trolley derby, Miss Southland and a public art exhibition in a community hall. The lack of a local art gallery meant that visual art was not yet a strong part of Gore's community life.

\section{Missionary Zeal (1983 -1987)}

In 1983 the Carnegie Library building in Gore became vacant when the library moved into new premises. The local Council invited expressions of interest for the building and the Gore and Districts Historical Society Incorporated ${ }^{2}$ floated the idea of opening a new museum and art gallery. The Historical Society knew about Geddes' art school background and invited him to a meeting, which resolved to establish an art gallery and form a new Incorporated Society (the Eastern Southland Gallery Incorporated) to realise this. Geddes was nominated onto the first committee but 'didn't initially see this as a career move'. Between October 1983 and May 1984, Geddes readied the Gallery for its opening as an unpaid volunteer and earned his living as a musician in his weekends.

The Eastern Southland Gallery opened in May 1984. Geddes continued working as an unpaid volunteer, organising and hanging exhibitions but a longer term view was forming:

The Gallery Committee was keen to charge artists a rental to exhibit but my vision was for a public gallery and I fought tooth and nail to avoid a booking system. I thought if I was investing my time, I wanted it to be worth it. This meant there wasn't any money for exhibitions but I knew artists from art school and from working at the Southland Museum and Art Gallery and we exhibited their work.

Two locals, Natalie Dolamore (the local librarian) and her partner Patric Carey (who established the Globe Theatre in Dunedin) encouraged Geddes to set a high bar. They were well connected in the arts community and encouraged friends such as Marilyn

\footnotetext{
${ }^{2}$ An Incorporated Society formed to collect, preserve and share Gore's local history.
} 
Webb and Ralph Hotere (well established Dunedin based artists) to exhibit and lend their mana to the new Gallery. Carey and Dolamore's circle of friends also included New Zealand writers Hone Tuwhare, Cilla McQueen, James McNeish and Janet Frame all of whom in their own way lent their support to the Gallery. Geddes' work enabled him to shift the committee's goal of a community art centre toward his vision of a public gallery. By September 1984, Geddes savings were exhausted and he did not know how much longer he could continue on as an unpaid volunteer. To solve this Geddes secured a six month, Artwork Project Employment Programme (PEP) Scheme which funded his first paid role at the Gallery.

The PEP scheme gave me the opportunity to prove the need for a permanent exhibitions officer. The six months went really quickly, we packed a lot of activity into it and we got community buy in as a result. I fed the media all the time, so we were seen to be a busy place.

In March 1985, Geddes initiated and secured a further twelve months salary via funding from a Volunteer Organisation Training Programme. 1985 saw the same pattern of regularly rotating exhibitions. There was also an element of personal investment:

The committee didn't have any money, so when we got a show we would try and sell one or two works. Invariably I'd pay for a work, it got messy. But a couple of core supporters also helped by also buying works.

Initially the two (then) local bodies, the Gore Borough Council and the Southland County Council, refused to provide grants to staff the Gallery, citing their existing commitment to the provincial Museum and Art Gallery in Invercargill. Geddes said:

It was tempting to get annoyed and thump tables but in the long run more was achieved by accepting rejection with polite wide eyed innocence while maintaining a very short memory. Patient lobbying [by Geddes] eventually paid off, and with the aid of the local media, the attitude of the funders weakened.

By late 1986, the Gallery had a commitment from the above local bodies and one Trust for on-going contributions to a modest salary for one exhibitions officer. The annual grant was approximately $\$ 7,000$ and while administered by the Gore Borough Council the Gallery remained autonomous from the Council. The grant increased incrementally but Geddes recalls, each year: 
Having to swallow my pride about my income being in the public domain. It was the same for the Forrester Gallery in Oamaru, the Millennium Gallery in Blenheim and the Left Bank in Greymouth. There wasn't any guarantee for long term funding, few galleries were part of local authorities at that time.

To this point the main focus of the Gallery's committee was on raising an endowment fund with the aim of paying operating costs from the interest generated. The 1987 New Zealand share market crash stymied that plan and as a consequence Geddes continued to multi-task as curator, graphic designer, exhibition technician and administrator, on a shoe-string budget. Geddes struck up a good relationship with the Dunedin Public Art Gallery and would volunteer there for a week at a time to help prepare exhibitions. He recalls 'this was a good way to up-skill and be a part of the wider sector'. Geddes summed up the first five years as a period of 'consciously reinforcing the positive benefits of having an art gallery in Gore and nurturing an incremental increase in public support for it'.

\section{Courting Stakeholders (1988 - 1992)}

In 1988, Geddes set out his vision for what he hoped the Gallery would provide:

Ultimately, as finances build, an important function of this facility will be to try and make it worthwhile for artists to come south. We will try and maintain a close association with those who do exhibit here and provide as much support as we can, but projects, installations, commissions, residencies (and a care-free environment to work in) keep artists going and the viewing public benefits from being exposed to fresh, new, vibrant experiences. ${ }^{3}$

When I asked about the Gallery's then financial position, Geddes readily conceded that it was 'constantly operating in the red' and needed to attract outside financial support. To up-skill in this area, in 1988, Geddes accepted an appointment to sit as regional representative on the Lotteries Grant Board's Communities Facilities Committee, a role he performed for the next nine years. 'This was useful, as I saw how funding worked in the bigger scheme of things'. The following year, Geddes put the Gallery's success to date down to:

'energy, innovation, dedication and enthusiasm. Budget and special constraints can be worked around; they are nagging but minor problems ${ }^{\prime .4}$

\footnotetext{
${ }^{3}$ Jim Geddes, "Eastern Southland Gallery - Gore,” AGMANZ Journal, no. 19.1 (1988): 9.

${ }^{4}$ Jim Geddes, Exhibition Officer's Report, Annual Report (Gore: Eastern Southland Gallery, August 2, 1989).
} 
The reorganisation of New Zealand's local bodies in 1989 presented opportunities for the Gallery as the District's Borough and County Councils amalgamated to form the new Gore District Council. One of its prescribed tasks under the amalgamation legislation was to set a cultural policy for the District. Geddes readily agreed to assist with this exercise and carefully positioned the Gallery and new Gore Historical Museum (which opened in 1988 in Gore's old fire station) within this local body framework. As an aside, Geddes was not formally connected with the Museum but maintained close links with the Gore Historical Society by helping its volunteer members with collection management and interpretation on a pro bono basis. As part of the new cultural policy, Geddes successfully lobbied for a museum assistant with shared duties between the Gallery and Museum. This staffing support reinforced the existing relationship between Geddes and the Historical Society and set a path for the parallel development of the Gallery and Historical Museum.

In late 1989, Geddes received a Southern Regional Arts Council grant for a two month study tour of regional galleries in the United States of America. It was during this trip that he first met the expatriate New Zealand psychologist, Dr John Money. Geddes' travelling companion knew Dr Money's niece and suggested they pay him a visit while in Baltimore. Dr Money made time for the two Kiwis, invited them to his house, showed them his art collection and shared his connections with the New Zealand writers James and Jacqueline Baxter, Janet Frame and the artists Theo Schoon, and Rita Angus. Money corresponded with Geddes after the visit, sending him exhibition and art related news. This relationship ultimately led to Money gifting his entire art collection to the Gallery in 2000.

During this era, the Gallery's exhibition programme was pared down to a ten show quota augmented with musical, theatre and poetry performances. Geddes encouraged the Gallery committee to start building a collection of works, initially with an emphasis on the local. After returning from the United States, Geddes instigated more community based programmes, including an artist in residence programme and developed the cross links between contemporary art and local heritage with exhibitions such as Murihiku (the South Land) and the late Trevor Moffitt's Prohibition series. 
Geddes cited persistence as the main quality he developed during these years. He says he also became more confident dealing with artists and felt that he was working 'for all the right reasons'. When I later asked what this meant, he said 'for the ultimate benefit of the community, something that is going to be permanently here and be of value to the District, rather than of value to me'. ${ }^{5}$ Geddes also reflected on a point of difference in that other curators did not always open their homes to visiting artists preferring a professional distance. Geddes feels that hosting visiting artists 'cultivated friendships and trust'.

\section{Calling All Councillors (1993-1997)}

Geddes felt that the Gore District Council's establishment of a Department of Arts and Heritage in July 1996 was the most significant development in this next period. This move implemented the recommendations of an unpublished report prepared by the then Otago/Southland Museums Service Liaison Officer, Gerard O'Regan. In short, the Council agreed to fund staff for basic programme, collection and development management for the Eastern Southland Gallery, the Gore Historical Museum and a proposed new cultural tourism attraction based around the tension between prohibition and the distilling/bootlegging of Hokonui Moonshine (whisky) in Eastern Southland. The new Department was also charged with providing professional assistance to the District's small volunteer museums. Geddes' new job title was District Curator and for the first time he received a market salary, ${ }^{6}$

This was a real endorsement of what we were doing. By that stage I had, had twelve years of cycling temporary exhibitions with minimum resources; the permanence of an annual budget was motivating. But the success of some of those early shows helped people respond to the place. We were onto a winner for the community, who felt that their place and their stories were valued. We were different to the Council's other departments. While the Council 'owned' the staff, it didn't own the resources the staff worked with. This gave us a good deal of freedom, administrative freedom. The advantages of becoming a Department of the Council have been salary resourcing, access to the Council's resources (such as insurance facilities) and a budget for custodial staff which meant that I could take holidays. ${ }^{7}$

\footnotetext{
${ }^{5}$ Jim Geddes, September 27, 2011.

${ }^{6}$ A market salary was benchmarked by the accounting firm Deloittes.

${ }^{7}$ Jim Geddes, September 22, 2011.
} 
Ownership of the facilities and collections remained with the founding Societies as did the responsibility for funding their programmes and activities. The Departmental structure enabled the Council to meet its District Plan obligations of supporting the District's heritage and cultural initiatives but stopped well short of any obligation on the Council to own, manage and collect art, artefacts or the buildings that housed them. The Department also assumed responsibility for the District Council's Historic Places, Creative Communities and Heritage Registers. Geddes recalls:

An immediate difference was that rather than being consulted as part of the District planning process, we began to be asked to generate ideas and directions in the broadest of terms, from District marketing and economic development strategies.

In this vein, Geddes proposed a new facility called the Hokonui Heritage Centre to house five facilities: the District's Information Centre, the Historical Society's Museum and collection, the proposed Moonshine Museum and a new local history and genealogical Research Centre. Geddes argued that this would solve a number of problems for the Council. Its then Information Centre was in a prefabricated building and the Historical Society's Collection was in an old brick fire station that did not provide safe museum display and storage standards. The proposed Hokonui Moonshine Museum project was also floundering with a local volunteer organisation. The new facility promised to bring all these loose threads together. The Information Centre staff would also provide a front of house presence for the Museums. The new Moonshine Museum would introduce a cultural tourism element by providing more of a visitor attraction element with whisky tastings and sales. A new collection store would also provide more stable storage for the Museums' collections. The Research Centre would bring together the Historical and Genealogical Societies' resources and a part-time research officer would field public queries.

The preferred site was an older style supermarket directly across from the Gallery, which the owners were willing to sell. It was a neat solution on paper but it had to be paid for. This was Geddes' first major capital development project, with a total budget of $\$ 1.3$ million, $\$ 490,000$ of which was for the land and buildings. Planning, fund raising and fit out of the Hokonui Heritage Centre dominated the period from 1997 through to 2000. For Geddes it reinforced the importance of designing and tabling solutions to the Council rather than presenting it with problems. Parallel to all this, in late 1996, Dr John Money wrote to Geddes asking if he knew anyone in New Zealand 
who might be interested in his Collection. Over the next eighteen months, Geddes approached various cultural sector organisations such as Te Papa, ${ }^{8}$ the Ministry of Culture and Heritage and Creative New Zealand.

None of them were of any real help; they didn't seem to get it. At that stage, all I was trying to do was catalogue John's collection and bring it home. I didn't see Gore as an option at that stage because we were focused on the local, the acquisitions policy was narrow and the Gallery's focus was on temporary exhibitions.

That is where matters sat as regards the Money Collection until 1998.

\section{Construction phase (1998 - 2002)}

Work on the new Heritage Centre occurred between 1998 and 2000. To ensure community ownership, two new charitable trusts were formed, one to own the land and fixtures (the Hokonui Heritage Trust) and a second to own the Hokonui Moonshine Museum (Hokonui Moonshine Museum Charitable Trust ) which had the task of generating an income through admission fees and the sale of whisky-related merchandise. The Historical Society sold its old fire station building and settled the proceeds on the new Heritage Trust. Geddes sought funding assistance from the Mataura Licensing Trust. ${ }^{9}$ The Mataura Licensing Trust saw the potential and together with the Community Trust of Southland provided the core funding for the project. The new Gore Historical Museum opened in 1999, followed by the Hokonui Moonshine Museum in 2000.

Returning to the John Money thread, Geddes recalls that by 1998, 'John was getting despondent about the prospect of finding a home for his Collection in New Zealand'.

Geddes felt an obligation to Money, arranged a personal overdraft and flew to Baltimore for a week to catalogue and photograph Money's collection.

It was only on the last day, the last couple of hours that we started talking about where his collection could fit in. He might have nailed me about the funding of the trip. I wanted to give the impression that his collection was valued.

\footnotetext{
${ }^{8}$ The Museum of New Zealand, Te Papa Tongarewa

${ }^{9}$ A statutory Trust with a monopoly on the sale of liquor in Eastern Southland responsible for distributing its profits back into the local community
} 
This is when Money first asked if the Eastern Southland Gallery would consider taking his Collection. On Geddes' return to New Zealand he sent the catalogue to Te Papa, the Canterbury and Otago Museums, as well as the Dunedin Public Art Gallery. Both Peter Entwistle from the Dunedin Public Art Gallery and Russell Beck in Invercargill encouraged Geddes to make the project happen in Gore:

I then thought long and hard about how we could accommodate John's collection here. I started selling it to the Gallery Committee. Not the whole committee, just key people on it, especially the younger ones. I was also conscious that we needed to get the new Museum finished before taking on anything new.

After the opening of the Heritage Centre, Geddes immediately turned his attention to bringing Dr Money's Collection to Gore. After securing the support of the full Gallery Committee, plans were drawn for a new wing and for a general redevelopment of the Gallery. The projected cost was $\$ 1.2$ million. Geddes' next step was to enlist the help of Bill English (the Member of Parliament for Clutha Southland) to acquire adjoining land from the Department of Justice and for help with the international tax issues. Here, Geddes relates some of those challenges:

Bill was very helpful and made one of his staffers available. Bernard Cadogan helped us work through multiple logistical challenges as there wasn't the experience to call on in the museum sector. Bernard sniffed out a USA tax expert based in the US embassy in Singapore. She was working with Australasian charitable foundations with US interests and was a specialist in clause 5013C which provided for limited charitable status for off shore charitable entities. She advised us to apply to the IRS for that status. It proved a mammoth task but we got it for 5 years with a right of renewal. Funnily enough we also had to sign an affidavit certifying that we didn't have any communist affiliations! We didn't renew but it did mean that when John died, his endowment to us was tax free.

In June 2001, New Zealand's then Prime Minister, Helen Clark launched the Gallery's fund raising appeal, announcing a \$400,000 grant from the Lottery Grants Board. The Community Trust of Southland agreed to match this sum. The Mataura Licensing Trust committed close to $\$ 200,000$. Additional grants came from the Ministry of Culture and Heritage's Regional Museums Fund and the Ministry of Tourism's Facilities Development Scheme. The balance was raised by way of public sponsorship. Not for profit professionals familiar with large capital development funding applications will appreciate the work and attention to detail required to achieve this. In typical understatement, Geddes said 'we managed the project in a fun way and always kept a positive spin'. You get a sense of this fun in the June 2001 
issue of Museums News, which includes a photograph of Helen Clark, with an expansive smile, holding a presentation bottle of Moonshine at the above launch. The cover of the same issue also announces the artist Ralph Hotere's gift of twenty five large works on paper to the Gallery to complement the Money Collection. Writer Janet Frame visited the Gallery at key juncture points to promote the project and lend her goodwill. So it is fair to say that Geddes successfully managed to enlist the support of New Zealand's leading politicians, artists, national and regional funders, as well the local community to realise the project. Building work commenced in 2002 and the Collection was packed and shipped to New Zealand later that year.

\section{More Projects (2003 - 2011)}

The John Money Wing, the Ralph Hotere Gallery and refurbished Gallery officially opened in December 2003. Here is part of what Helen Clark had to say at the opening:

The credit for this project is widely shared. It began with the vision of Jim Geddes and his team for what the Eastern Southland Gallery could be, and for the role which Gore could play in the visual arts. Those with a vision have a capacity to inspire others to back them, and that is what has happened in Gore........All these developments are part of what North \& South described as an art chain reaction, which has also seen Gore become a destination for visiting artists, art exchanges, and significant exhibitions. What has happened here is in truth inspirational. It's been a partnership between those with the artistic vision, those who have become substantial contributors to the Gallery's collections and all those who have clubbed together to fund the expansion of the Gallery and the transportation of the new works to it. ${ }^{10}$

Since the completion of the John Money project, Geddes has juggled five other main projects. The first dates back to 2001 when the Gallery purchased a deconsecrated Presbyterian Church in Gore with a view to renovating it and establishing a studio, artist's flat and performance centre in order to realise the aims signposted in Geddes' 1988 AGMANZ article. Frans Baetens and Magda van Gils the owners of Muka Print Studio in Auckland, have gifted their Voirin lithographic press and studio equipment to this project. The artist's flat is ready, the press is currently being shipped to Gore and the studio is scheduled to be finished by May 2012. This project is taking considerably longer than the Heritage Centre and John Money projects because the dilapidated condition of the church buildings requires more work than a rebuild and

\footnotetext{
${ }^{10}$ Helen Clark, "Eastern Southland Gallery" (Speech presented at the Opening of the John Money Wing, Gore, December 12, 2002).
} 
the project has had to be staged in deference to the project's two key funders ${ }^{11}$, and a general slowing in the local economy since 2008.

The second project involves Geddes helping a separate Aviation Heritage Trust $^{12}$ to establish a civil aviation museum at Mandeville, fifteen kilometres west of Gore. This is effectively a hybrid consultancy and project management role in his capacity as District Curator. Again this project has had to be staged. The Trust's collection of aircraft and associated hanger are ready. The final stages require funding for front of house displays and interpretation of the collection.

The third project involved the purchase of commercial land and a building on a site adjacent to the Heritage Centre to facilitate the Centre's future expansion. To secure the property when it came up for sale in 2007, the purchase was funded by the Gore District Council using a special consultative procedure as the purchase was outside the Council's annual and LTCCP ${ }^{13}$ plans. The fourth project is called Southern Odyssey and is effectively a District wide cultural heritage trail. Its distinguishing feature is that it uses businesses and other public places to profile cultural and historical characters. For example, the poet Bill Manhire grew up in Mossburn where his parents were the publicans of the local hotel. Geddes commissioned the Southland based artist Nigel Brown to paint a portrait of the young Manhire. The portrait and the Manhire poem that inspired it now hang in the Mossburn hotel. This example simply demonstrates the outreach nature of the project designed to celebrate local culture and heritage and make it more accessible.

The fifth project involved advocating for a roving museums officer to support Southland's volunteer museums. This was not entirely altruistic as Geddes often found himself doing work for existing and proposed museums in the region:

This involved to a degree working with the former museum liaison officers who were funded by the Lottery Grants Board and who did what National Services now do to a degree. But their patches were too big, they didn't do hands on work and their host organisations had considerable call on them.

\footnotetext{
${ }^{11}$ The Community Trust of Southland and the Mataura Licensing Trust.

12 The Croydon Aviation Trust.

${ }^{13}$ Long Term Council Community Plan, a requirement of the Local Government Act 2002.
} 
Geddes saw the opportunity to lobby for a hands on Southland roving museums officer. The regional planning entity, Venture Southland lent their support because their community developments officers were getting frequent requests to help small museums that they were not equipped to deal with. Southland's three territorial authorities and the Community Trust of Southland agreed to co-fund the new position, which started in early 2007. Geddes is the appointee's supervisor. Geddes has managed these five projects around the Gallery's normal exhibition and performance programme. I have not dwelt much on this programming aspect of his career on the basis that it is the staple of a gallery director's role. When reflecting back on these last eight years, Geddes' said:

I have been trying to build capacity on a whole lot of levels. I have been endeavouring to endear the Department to an expanded range of stakeholders. I have had the luxury of being able to do things off my own bat without very formal consultation and approval processes. Having a supportive bunch of people in governance roles provides the scope for that.

In 2008 Geddes won the inaugural Museums Aotearoa Individual Achievement Award. Judging panellist Jenny Gibbs noted:

Jim Geddes has made outstanding contributions in putting Gore on the national cultural map, including his single-handed work in founding the Hokonui Heritage Centre in Gore, the Eastern Southland Gallery, development of the Croydon Aviation Museum, and expansion of Gore's Historical Museum. Jim has also been recognised for his work in acquiring major gifted additions to the gallery's collection including works by Ralph Hotere and Dr John Money. ${ }^{14}$

\section{As the Media see it}

To round out this first chapter, I now present a short survey of how the print media has presented Geddes' work. Up until the start of the John Money project the vast majority of press coverage was local and involved the two District newspapers profiling upcoming or current exhibitions. Higher profile exhibitions would merit a feature in the regional daily. ${ }^{15}$ Interestingly there was little in the way of exhibition reviews. The general impression is of an enthusiastic gallery director presenting an active programme. This type of reporting continues but another pattern emerged around the time of the John Money project. For the first time, the national media took

\footnotetext{
14 “Museums Aotearoa, Media Release, 2008 Individual Achievement Award”, April 10, 2008.

15 The Southland Times
} 
an interest in Geddes' work. In December 2003, North and South magazine ran an article profiling Geddes' career, tracing the major projects, interviewing stakeholders, telling the John Money (and friends) story and challenging the cliché of Gore as a hick rural service town. ${ }^{16}$ Larson's article refers to a 'confluence of extraordinary individuals ${ }^{17}$ and 'an art chain reaction, ${ }^{18}$. A quotation from Ian Tulloch, a businessman and ex-mayor of Gore comments on Geddes' professional practice:

Jim is not a stereotypical arty person. He has artistic flair and an infectious personality but he's also very astute financially. He's not at all materialistic personally. He worked for years for next to nothing before the Council put him on the payroll. But he does have a business brain and he understands how to achieve his objectives through long-term strategies. He allows others to catch his vision piece by piece. ${ }^{19}$

A similar article appeared in the November 2003 issue of the Listener but with more focus on Ralph Hotere's gifts to the Gallery. The article quotes Frans Baetens, a director of Muka Studio who opined:

There are a lot of people in the arts world who are directors of a museum in one place, then another, always as part of a career development. But Jim, he comes from Gore and he works for Gore, he's determined to stay local. He's working to bring contemporary art within reach of smaller communities. In a few more years Gore will develop into one of our cultural tourism places where people visiting New Zealand will have to go. ${ }^{20}$

Baeten's quotation reveals both Muka's motivation to gift their lithographic press to the Gallery and the sense of place that underpins Geddes' career. The following year Joanna Cobley reviewed the developments in Gore from a more museological perspective in an article for the journal of Museums Aotearoa, Te Ara. ${ }^{21}$ Cobley noted the emphasis given to regional points of difference and also strategic alliances between the museums of Gore and their communities. ${ }^{22}$ She identified the various Charitable Trusts and Incorporated Societies under the Department's umbrella and expressed this as 'an amazing human grapevine' ${ }^{23}$ enabling Geddes' Department to

\footnotetext{
${ }^{16}$ Virginia Larson, "The Fine Art of Gore," North and South, December 2003.

${ }^{17}$ Ibid, 99.

${ }^{18}$ Ibid, 103.

${ }^{19} \mathrm{Ibid}, 101$.

${ }^{20}$ Blundell Sally, "The art of being Gore," New Zealand Listener, November 15, 2003, 23.

${ }^{21}$ Joanna Cobley, "Sex, booze and museums: a heady cocktail in Gore," Te Ara 29, no. 1 (May 2004): 16-20.

${ }^{22}$ Ibid, 18 .

${ }^{23}$ Ibid.
} 
'discover and leverage opportunities that could be sorely missed or ignored if it were differently structured'. ${ }^{24}$ Cobley concluded:

The community that supports the Eastern Southland Art Gallery and other museum enterprises represents a complex overlay of local, national and international individuals and organisations....Significantly, whether small and regional or large and urban, the arm of friendship from the staff of the Department of Art and Heritage reaches out wherever it is required. The unquestioned support that can radiate from a modestly resourced regional museum unit not only instantly attracts mutual respect but also nurtures the desire to return the favour. To me, this reciprocity of the Eastern Southland Art Gallery is one of the secrets of the successful expansion of the Gallery and the museum enterprises of Gore, present and future. ${ }^{25}$

In November 2005, the NZ House and Garden on Holiday issue profiled Gore and contrasted its reputation as a small 'hick' town against the new cultural tourism opportunities. A number of these tourist orientated articles have followed in such publications as AA Directions magazine ${ }^{26}$ and NZToday, Journeys through Our Heartland. ${ }^{27}$ These articles all tell a similar surface level story but they do give credence to Baeten's 2003 prophesy that Gore would become a cultural tourism destination. In conclusion, the success story of Geddes and his work with the local gallery and museums gave him a much higher profile, but once again begged the question - how did he achieve such results in a small town like Gore? Having set out Geddes' organisational and cultural context, I now shift focus in the next chapter to a consideration of his leadership practices through a series of interviews.

\footnotetext{
${ }^{24}$ Cobley, "Sex, booze and museums: a heady cocktail in Gore."

${ }^{25}$ Ibid, 20.

${ }^{26}$ Glenys Bean, “Small Town Surprise," AA Directions, Winter 2008.

${ }^{27}$ Allan Dick, "Gore and More," NZToday, Journeys through our Heartland, February 2008.
} 


\section{Chapter Two}

\section{Leadership Interviews}

\section{Introduction}

The last chapter laid out the background to Jim Geddes' museum career in Gore in order to provide the context for this research. The purpose of this chapter is to present Geddes' own assessment of his professional and leadership practices as well as the assessments of representatives of community, funder and employee stakeholders. Chapter two focuses on the practice component of the theory and practice equation, whereas the next chapter compares the two. It begins with an in-depth analysis of Geddes' leadership examined through several interviews and is structured under a series of headings or themes which emerged from the analysis of the interview data. I quote the interviewees extensively, so that their views and voices come through.

\section{Successes}

How does Geddes himself see his success as District Curator? Firstly, he sees his successes as a leader as:

Establishing a couple of sustainable facilities supported by a departmental structure. Generating a healthy degree of community buy in and a trusting rapport with key funding agencies that support capital and project development. Being a leader has never been a conscious thing, I have just seized opportunities and realised them the best way I knew how, there was no management plan for that, I'm not a leader in that respect. ${ }^{1}$

When I asked Geddes for his view of leadership, his slightly impatient reply was 'I don't know; I don't really understand it all'. He was more comfortable with a project oriented discussion than a conceptual analysis of leadership. Geddes considers that his professional achievements have been a 'happy collision of opportunities, the result of the personalities and the trust that has evolved'. Geddes added, 'I guess in leadership terms what I have achieved has been the ability to sell ideas to people and being able to stick it out when any normal employee would probably have walked away'. Implicit here, is that the first part of Geddes' career involved a large measure of voluntary and under remunerated work. Geddes said he stuck at it because, 'I don't

\footnotetext{
${ }^{1}$ Jim Geddes, September 27, 2011 (subsequent quotes are from this interview, until indicated otherwise).
} 
like walking away from ventures that I have encouraged other people to invest in and that I have also invested in, so I have a stake on a whole lot of levels'.

To back up his assessment of a 'healthy degree of community buy in', Geddes referred to his Department's record of gaining the highest satisfaction rating in the Gore District Council's 2008 and 2010 rate payer surveys and said 'clearly the community values what we are doing'. Geddes also identified a positive relationship with the media as an important element of his success: 'it is a relationship that we have built up over the years and I'd like to think it is a trusting one. They are an important part of the set up'. Geddes places a high degree of importance on positivity, noting: 'one of the biggest mistakes that people can make is to feed bad press into the media with a view to scaring up resources, it usually just turns stakeholders off'.

\section{Challenges}

An important aspect of leadership is how people respond to challenges. Geddes indicated that one of his biggest challenges has been 'getting peoples' heads around possibilities and believes that his "personal investment of time and immersion in projects' has helped with this because 'the community, the Council and funders see you as going the extra mile and perceive your efforts as being for the right reasons'. Geddes said his 'toughest nut to crack' ${ }^{2}$ was gaining the full support of the Gore District Council. His strategy here was gradually to win the general support of ratepayers, councillors and senior Council management. Chapter one relates how Geddes worked with Council management, using its cultural policy, annual plans and LTCCPs $^{3}$ to embed his goals into the Council's structure. To gain the support of the Councillors, Geddes identified their various communities of interest and then mixed within these groups, selling his projects so that the Councillors' feedback loops were generally supportive of his work, thus giving Councillors the confidence that cultural spending would not anger voters.

\footnotetext{
${ }^{2}$ Jim Geddes, September 29, 2011 (subsequent quotes are from this interview, until indicated otherwise).

${ }^{3}$ Long Term Council Community Plans
} 
Geddes also referred to the challenge of shepherding funders toward granting further resources to the arts and 'getting them to feel good about it.' By way of example, Geddes referred to successfully inviting the CEO of the Mataura Licensing Trust to be a trustee of the Charitable Trust that owns the Museum complex. Geddes saw this as a way of 'maximising the Trust's input within a wider cultural context and helping them to instil a creative edge'.

When asked about any failures along the way, Geddes' diplomatic reply was: 'everything has been a failure to a degree, in that we have never realised the potential of the facilities'. Geddes referred to a lack of resources resulting in having to 'constantly revisit projects' because they cannot always be fully refined. He said he 'doesn't get so bothered by this now' and sees this aspect as presenting 'future opportunities'. Geddes then made the point that some people in the museum sector can get 'too precious about their reputation, resulting in conservatism and a habit of sticking to the done thing'. From my own observation of his practice, it seems to me that Geddes is willing to realise the major outline of a project and let the finer operational details such as collection management systems for example catch up over time.

\section{Vision and Motivation}

A further indicator of leadership is the ability to articulate a clear vision and motivate oneself and others to achieve it. Geddes does not think that his overall vision changed that much over the years. It always involved a Public Art Gallery that 'encouraged the development of work that celebrates this place'. He cited the Hokonui Moonshine Museum and the Muka Studio as examples of this. Geddes sees the new Muka studio and artists' residency as an opportunity to 'get artists here and allow them to respond to the place'. Geddes then listed a series of locally focused exhibitions and the recent Southern Odyssey project to make the point that it is 'harder for local people to dismiss contemporary art if it is about their place'.

Right from the establishment of the Gallery, Geddes resisted the push for an arts centre that hired out its space 'I could see it being much bigger and better and felt the community had their blinkers on because they didn't see the potential to sustain a 
Public Gallery'. Geddes felt that he was in a position [as a young single person] to 'give it a go' and did not see any reason why he could not. He also felt his band experience helped because playing music professionally was about 'having a vision, putting yourself in a vulnerable position, personally and financially and going for broke'. Geddes says his work experience in the Southland Museum and Art Gallery also helped him to see the potential for the parallel development of the Gallery and Museum but that timing-wise it was easier to start with the Gallery.

Geddes is motivated by uncovering local stories and by sharing the company of the artists that exhibit at the Gallery. He enjoys developing lesser known aspects of local heritage because 'there is still sufficiently uncharted territory to motivate me'. A stubborn streak and desire to prove naysayers wrong also came through in our interviews, or as he put it, 'I guess, I've never let it go'. A strong desire to pass on sustainable facilities also emerged. Referring to the John Money project, Geddes told me 'what we did was one thing but making it sustainable was a bigger challenge. The only way to do this was to stick with it and develop it'. Working with limited resources (personnel and financial) has been a feature of Geddes' career:

When I first started I wondered how I was going to pay the bills at the end of each month. Even now when we have a departmental structure and endowment funds. I still ask the same question because we are constantly extending and realising more ambitious projects.

Geddes then joked that he must like working in a state of change because he is still doing it and that constant improvement and capacity building kept him going. He thought it would be awful to run a fully set up organisation and programme and relished 'the freedom to re-invent things and to be able to respond to community needs'.

\section{Mentors}

When asked if mentors had played a role in his career, Geddes referred first to Russell Beck (a retired Southland museum director and sculptor) because Beck initially trained Geddes and because he has remained a sounding board throughout Geddes' career. Geddes then referred to James Mack (aka Galvan Macnamara, the New Zealand art curator and museum director) whom Geddes admired for his 'enthusiasm' and for 'marrying the creative aspects of his work with a sound historic knowledge'. 
Fleur Sullivan, the Otago restaurateur, also influenced Geddes when he worked for her as a musician in the early 1980s at her then restaurant Oliver's in Clyde. Geddes was struck by 'Sullivan's total dedication to excellence, her innovation and her bravery for sticking with it'. Geddes recalled the freshness of Sullivan's menus, their regional focus and how they were 'out of sorts with a steak and chips convention. She realised that the only way to grow her local clientele was for visitors to say how good it was'. Geddes felt that this was a good recipe to apply to his fledging art gallery. The last person Geddes mentioned as a mentor was the late Patric Carey (a pioneering theatre director) whom Geddes admired for producing serious independent theatre and drawing together a community of artists of different genres around Dunedin's Globe Theatre. As already noted, Carey and his close friend Natalie Dolamore were early supporters of Geddes' projects and instrumental in introducing a number of patrons to the Eastern Southland Gallery.

\section{The role of a museum leader}

Useful insights can be revealed from a leader's own perception of leadership and I asked a series of questions around this topic. Geddes sees a museum leader's role as building capacity across an organisation using a collaborative approach. He settled on the analogy of a theatre director, responsible for the oversight and orchestration of a play but qualified this by adding 'that there wasn't a set script to follow' and he often 'made it up as he went along'. He takes the view that 'micro-control is corrosive' and that control of the 'big picture requires a loose hold of the reins, so that other influences can help refine the overall vision'. When asked about the role that emotion plays in the exercise of leadership, Geddes reiterated the importance of a leader having a clear idea of the big picture but that you 'can't walk over people to get to your goals' and that 'you have to have emotional buy in for things to reach their full potential'. Geddes said he relies on his intuition a good deal of the time, observing 'when I haven't gone with my gut instinct, I have invariably regretted the decision'. However he tends to be more conservative when selecting major projects and in those cases 'I mull on it and consult fully before making a game call'. When asked to assess his leadership style, Geddes said 'I see opportunities and see them through'. He feels that he is able to 'bring partners on board and give them the confidence to be to involved and stay on board'. Geddes sees his personal leadership attributes as 
'enthusiasm and commitment'. He also places a high value on civility, indicating that it was very rarely worth entering into a confrontation and that his preferred approach was to 'take a step back and manoeuvre'.

\section{Stakeholder Relationships}

Much of Geddes' time is taken up with managing stakeholder relationships. His strategies for building and fostering relationships with stakeholders are: to be involved in a range of community projects [not just his own], patience and 'an awareness of where other things sit on the cultural map'. Geddes referred to his speaking and arts judging engagements, membership of several local service and social clubs and involvement with the annual Hokonui Fashion and Design Awards and Gore's Southern Field days. He said, 'you have to do your share and not just be on the take, otherwise you are just seen as needy'. From my observation another recent example Geddes could have cited is his assistance to the Mataura Licensing Trust in branding a heritage themed bar and café in Gore. As part of its resource and building consent the Trust had to retain and upgrade a historic building frontage. In conjunction with Geddes the Trust settled on a brand around Gore's first mayor 'Thomas Green'. Geddes helped with resources from the Gore Historical Museum and worked with the Trust's graphic designer to develop the brand. Geddes' work was pro bono in recognition of the Trust's assistance to his Department and likely to have been in the knowledge that part of Gore's heritage would be exposed to a wider audience. Geddes sees his involvement in the community as an opportunity to get to know people and to engage which 'opens a mine of information and opportunities to share information and to float ideas on an informal basis'. Similarly he never underestimates the power of speaking opportunities and school visits and sees them 'as a foot in the door to the wider community'.

\section{Why Gore?}

When asked why he has based his career in Gore, Geddes indicated that it was where his 'opportunities have been" 4 and that it has provided him with 'the opportunity to start something from scratch, to work on multiple levels without getting pigeonholed

\footnotetext{
${ }^{4}$ Jim Geddes, October 6, 2011.
} 
in one role'. ${ }^{5}$ For the first part of his career he felt he was not in a position to go anywhere else and resolved that, if he was going to stay in Gore, he was going 'to make it a really interesting time ${ }^{6} \mathrm{He}$ also referred to a very strong sense of personal and family connection, explaining that 'when you have bones buried in the Mataura Valley you take a special interest in the place. This makes me want to know more about it on both a personal and professional level'. ${ }^{7}$ Geddes reports 'taking a real pride in trying to bring the best out of a place and wanting to do something that will ultimately benefit it. In that sense it hasn't been a career, it has been a lifestyle'. ${ }^{8}$ When asked what working in one place for twenty eight years has provided for him, Geddes responded in terms of motivation rather than skills or networks. He said: 'You wake up in the morning and want to go to work, you have interesting things happening all the time and I guess you get nourished by the energy of it all'. 9 Working in Gore provides Geddes with a sense of freedom to develop projects and facilities. He also sees 'tangible benefits, in terms of community buy-in over the years'. ${ }^{10}$

On the negative side of the ledger, under resourcing has been a perennial issue:

for the scope of our activities, we have nowhere near the resources we need. You always have to go and find them which is a very taxing exercise, often to get things that other places take for granted. Every time we want to do something, I have to think, how are we going to fund it? And if it requires specialist skills how are we going to import them?

Five to ten years ago, Geddes would have said his skills were transferable to another organisation but doubts if that is now the case, noting that 'every museum and community is different'. This is reinforced when Geddes works with other communities looking to establish or restructure a museum. He made the point that when 'they try and replicate what we have done here, it hasn't necessarily worked to the same degree'.

\footnotetext{
5 Ibid.

${ }^{6}$ Jim Geddes, September 27, 2011.

${ }^{7} \mathrm{Jim}$ Geddes, October 6, 2011.

${ }^{8}$ Ibid.

${ }^{9} \mathrm{Jim}$ interview. September 27, 2011.

${ }^{10}$ Jim Geddes, October 6, 2011.
} 
The strict demarcation of roles in a larger organisation would frustrate Geddes, who takes the view that he hasn't had the time or resources to fully acquire a number of specialist skills. Geddes is also driven by working in the Gallery and maintaining a direct connection with art and artists. He recounted attending five o'clock drinks at the home of a director of a national museum in Australia and being struck by:

The director's living room, it spoke volumes, I could have been in Harvey Norman's. There wasn't any interesting art or books; there was no sense of personality or passion. The Director wasn't a consumer of culture in any form, it was truly awful yet this person was managing one of the biggest cultural organisations in the Southern Hemisphere'.

Geddes feels that he is not suited to a purely management oriented role, as 'I'm not part of that world and don't want to be'. Other barriers to changing jobs would be recreating a new set of professional relationships and learning another institution's practices. He also felt that he has had insufficient time to be constantly exposed to contemporary art practice and as a consequence questioned his ability to direct collection practice at a national level [as opposed to a local or regional level].

\section{Future Leadership Aspirations and Challenges}

Geddes' leadership aspirations are to see his current crop of projects come to fruition and be sustainable. He considers that the Department's facilities are still, to a degree, in start-up mode and sees more scope for them to 'work together'. He wants to 'finish the almost finished things, future-proof the collections and revisit the Gallery's infrastructure and re-develop the Museum'. Geddes also expressed a strong desire to develop business opportunities and to this end personally lent money received from his mother's inheritance ${ }^{11}$ to the Hokonui Moonshine Trust to enable it to purchase a liquor distilling business and the intellectual property rights for Hokonui Moonshine. The plan is to distil whisky in Gore and market Hokonui Moonshine nationally in order to increase the Museum's income stream. Geddes anticipates 'a solid ten years of more development work before we get to long term sustainability'.

\footnotetext{
${ }^{11}$ Geddes lent $\$ 150,000$ to the Trust for a ten year term on an interest free basis to enable the business to establish itself and generate an income.
} 


\section{Advice for aspiring museum leaders}

Geddes suggested two career routes for aspiring museum leaders. First, 'go for broke and start from nothing, find an opportunity or community will and hijack it'. Alternatively 'identify a really useful set of skills within the sector and get a range of experience in mid and large sized museums locally and overseas'. Either way, he considered it important to be in roles where everything is potentially your problem, because this generates strong planning skills. Geddes sees the acquisition of leadership skills as resting on individuals and takes the view that all the sector can do to foster emerging leaders is to: 'be flexible, welcome people at all levels and make opportunities through training, mentoring, internships and exchanges'. Geddes sees merit in selecting mentors from both inside and outside the museum/gallery sector and emphasised the need for aspiring leaders to acquire the business and management skills required to run departments within local authority and crown entity structures. For Geddes, leadership is about 'seeing opportunities and realising them'. He thinks this boils down to passion, capability and ensuring sustainable organisations.

\section{Network Analysis}

In order to represent Geddes' wide network of relationships, I asked him to draw a diagram summarising his roles and professional networks; the result is the 'onion ring' diagram [refer to figure 1 on the following page]. The two inner rings set out his core responsibilities as District Curator and the two outer rings represent the wider regulatory and sector framework. The diagram radiates out from the personal to the local and national. Geddes derives the most enjoyment and enthusiasm from working in the community (rings $3-5$ ) and observed that it easy for museum directors to remain 'safe and focus on core business responsibilities' but that this 'denies the chance to explore and develop wider networks'. Geddes said that 'unlike a lot of museum professionals, he does a lot of his work in the community space' and that this is where a spiritual element enters the role. He notices a trend toward unhappiness in museum professionals who work exclusively in the inner or outer rings because of the 'highly regulatory nature and focus on accountability of resources'. Geddes made the point that the 'rings' are fluid and feed into and out of one another. During our conversation, Geddes observed that his connections often turn into friendships and 
this enriches and strengthens the networks. After making this point, Geddes added a ring to the diagram to record professional friendships. Geddes identified rings 3 to 6 as his 'support networks'. As his networks have grown, he has noticed that they exert an inward pull and that this has strengthened since the completion of the John Money project.

Figure 1: Role and stakeholder/network analysis, J. Geddes, 6 October 2011

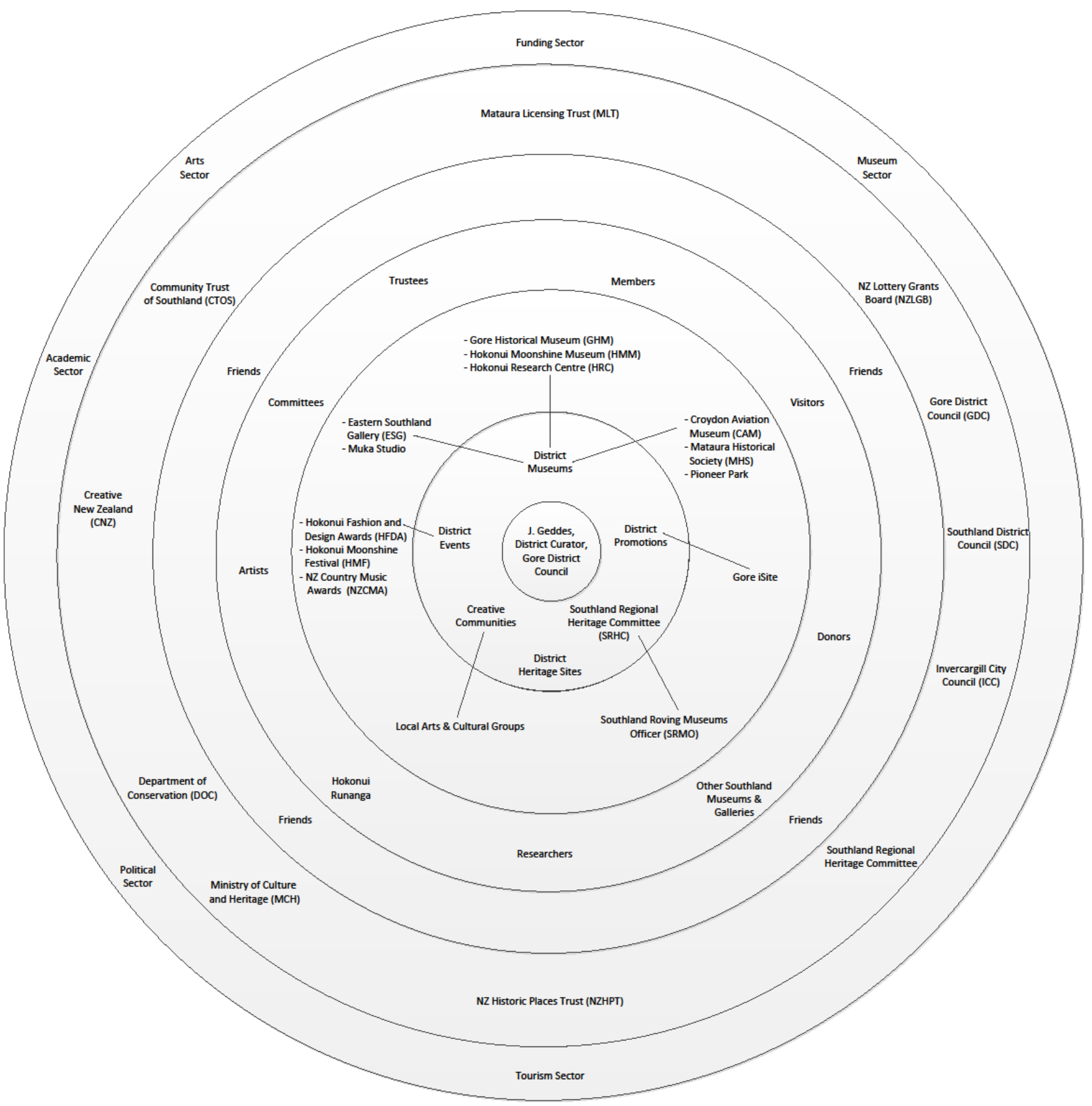




\section{Stakeholder Assessments of Geddes' Practice}

I interviewed representatives of three stakeholders to get their assessment of Geddes' practice from community, funder and employee perspectives. First I report on the perceptions of Mr Tracy Hicks, the Mayor of the Gore District Council and chair of the Community Trust of Southland. Hicks has known and worked with Geddes for fifteen years. Hicks considers that Geddes has a "relaxed laidback passion" 12 which is 'a quite unique combination'. Hicks finds Geddes to be a 'very understated' person who exceeds expectations, making 'on-going dealings that much easier'. Hicks related how Geddes is 'very interested in other peoples' projects in the community and will help where he can'. Hicks also outlined how Geddes 'likes to be very engaged with stakeholders' and realises the importance of 'keeping connections alive, even when he is not looking for support'. Hicks then went on to outline Geddes' working relationship with the Mataura Licensing Trust and observed that 'fifteen or so years ago the idea of the Trust supporting anything other than sport was almost unthinkable'. Hicks said that Geddes had 'broken that barrier' and attributes this to Geddes' 'relaxed non-threatening style that is able to communicate the benefits of a project in a clear way' and then 'go on to work very actively with organisations to achieve their aims'. By way of example, Hick's cited the 'Thomas Green' bar project, 'the [Mataura Licensing] Trust didn't know where to turn when they had to factor in heritage preservation resource and building consent conditions into their project'. Hicks related how Geddes helped the Trust work through these conditions and develop a local heritage brand for the new business. In essence, Hicks was articulating the reciprocity of the relationship between Geddes and the Mataura Licensing Trust. In his view, 'it serves the purposes of both very well and has also enhanced the community along the way'.

Hicks expressed the view that Geddes has almost universal support across the District and attributed this to the fact that his corner-stone projects [the Gallery and the Hokonui Heritage Centre Museums] were 'accessible, easily understood and professional'. Hicks also made mention of the media and felt that any comment or press story was 'always positive' and that there was:

\footnotetext{
${ }^{12}$ Tracy Hicks, September 15, 2011 (Hick's subsequent quotes are from this interview).
} 
a lot of media comment about cultural happenings in Gore and when local people read this, they feel very proud to be associated with what's going on, even if they don't necessarily visit, or actively participate or even understand it, but they do react very well to the positive image that is projected.

Hicks concluded by commenting on Geddes' relationship with the Gore District Council which gives Geddes, 'a lot of leeway to achieve his goals', citing a short notice decision by Council to buy a one million dollar property adjacent to the existing museum for future development when no one on the Council knew exactly what any redevelopment would 'entail or when it might translate into reality'. In Hick's experience with local government:

There has never been that amount of trust in any one individual. I think that if you asked any of the Councillors about the position of the heritage sector in Gore, none of them would have an exact answer but they do have faith in Jim and that his work is sympathetic to this area.

As noted in chapter one, Geddes has enjoyed considerable funding support from Southland's funding agencies, the largest of which is the Community Trust of Southland which makes annual grants of between $\$ 8$ million and $\$ 10$ million to Southland's not for profit sector. Accordingly I interviewed John Prendergast, the Trust's CEO who has worked with Geddes for the past thirteen years during which time the Community Trust has partially funded all of Geddes' major projects. When asked what personal attributes Geddes brings to his work, Prendergast described Geddes as being 'laidback with a genuine but understated approach' and pointed to Geddes' willingness to assist other Southland museums. ${ }^{13}$ Prendergast observed that Geddes is well-connected but modest with it and realistic in his funding applications. He referred to Geddes' 'ability to extract money from a whole lot of unlikely sources' and that Geddes usually comes to the Community Trust for assistance with the last part of the funding equation.

Prendergast said that Geddes has developed a track record of tabling interesting projects and achieving them without budget overruns. He also referred favourably to the way Geddes stages projects, 'breaking them down into digestible chunks, it suits him and it suits us, as we can see the progress with each stage before committing to the next'. Prendergast joked that Geddes was a 'recidivist grant applicant'. With some recidivists, Prendergast wonders 'what the hell do they want this time but with

\footnotetext{
${ }^{13}$ John Prendergast, September 26, 2011 (Prendergast's subsequent quotes are from this interview).
} 
Geddes he wonders 'what has he got for us this time?' Prendergast takes the view that Geddes' 'recidivism is tempered by the fact that his requests come in on the low side and he invariably has good projects'. He added that the Community Trust has never had a bad experience with Geddes' projects and puts this down to Geddes' communication: 'He lets you know the projects he has planned, he stages them for us and does what he says he is going to do'. Prendergast referred to Geddes' passion for Eastern Southland noting 'he keeps on coming up with things to enhance it'. Prendergast also lamented to a degree that Geddes prefers to work on projects within his District rather than at a Southland wide level.

Prendergast indicated that Geddes has 'built up an enormous bank of goodwill and credibility with the Trustees and referred to a recent application where one of the Trust's Grants Managers went back to Geddes suggesting he apply for more assistance because the first pitch was too low. Prendergast made the point that Geddes' dealings with the Community Trust are 'not just a transactional thing' and that it had evolved into an 'on-going partnership', joking that it was more like a marriage than a one night stand. When I asked if there was anything else I should factor into my research, Prendergast referred to Geddes' ability to 'marry up culture with commerce', referring to the Hokonui Moonshine merchandising, the distillery project and placing art and heritage narratives in hotels and local businesses as part of the Southern Odyssey trail. With reference to the Nigel Brown portrait of Bill Manhire that hangs in the Mossburn Hotel in Northern Southland, Prendergast said' you find out about all these links through Jim, it helps gives life and a context to heritage'.

Employees can provide useful insider insights into a leader's practice. With this in mind my third stakeholder interview was with Stephanie Herring who works as a parttime museum assistant at the Gore Historical Museum reporting to Geddes. Herring is a history graduate who has worked in the Museum since 2007 in a collection management and research role. The position evolved after Herring first served on the committee of the Eastern Southland Gallery. A fixed term contract at the Museum followed and after taking maternity leave Herring has a permanent position working three days a week. Part of the attraction of taking the job was 'to be part of something 
that was moving forward'. ${ }^{14}$ Herring sensed that the Arts and Heritage Department had a wide perspective and was not stereotypical Gore, which she referred to as 'closed and inward-looking'. Returning to Gore from London and finding this role was 'cool, appreciated and comforting'. Herring reported that Geddes generally leaves her to her own devices and that she found this a little disconcerting to begin with, until she spoke to a co-worker who told her 'the best thing I like about working for Jim, is that he trusts you, he knows you can do a good job and he lets you go and do it'. This advice 'clicked' with her and helped her see that she was being left to use her initiative to move the management of the museum collection forward. Trust is important to Herring and she feels that the trust Geddes affords her places a positive onus on her to produce work of a high standard. Herring sees Geddes as a 'hands off manager who takes time selecting his team' and then 'plays a supportive background role'. She said Geddes 'doesn't give you everything on a plate which makes you work through things yourself'.

Herring finds Geddes to be 'approachable, relaxed and open'. In this vein she referred to his open office at the front of the Gallery. 'He is the public face of the Gallery but it isn't a face', she said, 'he is that person'. She thinks Geddes' achievements are the result of 'hard work and taking opportunities with two hands'. She also reiterated the reciprocal sense of trust and strong relationships Geddes has built up with private and public funders: 'He knows he can trust them for money and they know they can trust him for a vision for Gore, that makes Gore attractive to others'. Herring referred to an inherent fluidity in Geddes' approach, citing several in-house projects that had stalled and had been deferred for lack of money. This comment helps explain Geddes' comment about his desire to 'finish the unfinished things'. An example of this is the task of recording all of the Museum's collection on Vernon (a computer based collection management system). This project will require thousands of hours of work and Herring's allocated time of two days a week for this task isn't enough to make quick progress. In short the project needs the allocation of extra resources that are outside of the Department's current staffing and financial budgets. Herring reported that Geddes supports her work by being 'available and happy to spend time answering questions' and assisting with her extra-mural, Museum and Heritage Studies course. When asked to describe the culture within the Arts and Heritage Department, she

\footnotetext{
${ }^{14}$ Stephanie Herring, September 23, 2011 (Herring's subsequent quotes are from this interview).
} 
referred to a 'team culture and cross-pollination of ideas'. She concluded that Geddes 'wasn't a conscious leader' and felt that people choose to follow him because of the attributes and skills she outlined during our interview.

After completing all the interviews, I reviewed the transcripts and identified the underlying themes, which I have summarised in the following table, listing the themes by the frequency in which they arose. The salient features of this table are discussed in the next chapter, suffice to say that it can be seen that the first ten themes are the strongest ideas that come through as they are mentioned by Geddes and all three of the stakeholders.

Table Three: Summary of Underlying Interview Themes

\begin{tabular}{|c|c|c|c|c|}
\hline Factor & Geddes & Hicks & Prendergast & Herring \\
\hline Trust & $\mathrm{X}$ & $\mathrm{X}$ & $\mathrm{X}$ & $\mathrm{X}$ \\
\hline Strong sense of place and community & $\mathrm{X}$ & $\mathrm{X}$ & $\mathrm{X}$ & $\mathrm{X}$ \\
\hline Passion & $\mathrm{X}$ & $\mathrm{X}$ & $\mathrm{X}$ & $\mathrm{X}$ \\
\hline Stakeholder Engagement (buy in) & $\mathrm{X}$ & $\mathrm{X}$ & $\mathrm{X}$ & $\mathrm{X}$ \\
\hline Professional/High Standards & $\mathrm{X}$ & $\mathrm{X}$ & $\mathrm{X}$ & $\mathrm{X}$ \\
\hline Strong fundraising ability & $\mathrm{X}$ & $\mathrm{X}$ & $\mathrm{X}$ & $\mathrm{X}$ \\
\hline Relaxed/laidback nature & $\mathrm{X}$ & $\mathrm{X}$ & $\mathrm{X}$ & $\mathrm{X}$ \\
\hline Strong Communicator & $\mathrm{X}$ & $\mathrm{X}$ & $\mathrm{X}$ & \\
\hline Able to identify and realise opportunities & $\mathrm{X}$ & & $\mathrm{X}$ & $\mathrm{X}$ \\
\hline Genuine approach & $\mathrm{X}$ & & $\mathrm{X}$ & $\mathrm{X}$ \\
\hline $\begin{array}{l}\text { Interest in other projects and a willingness to } \\
\text { help stakeholders }\end{array}$ & $\mathrm{X}$ & $\mathrm{X}$ & $\mathrm{X}$ & \\
\hline Accessible & $\mathrm{X}$ & $\mathrm{X}$ & & $\mathrm{X}$ \\
\hline Independent & $\mathrm{X}$ & $\mathrm{X}$ & & $\mathrm{X}$ \\
\hline Wide Networks & $\mathrm{X}$ & & $\mathrm{X}$ & \\
\hline Not a conscious leader & $\mathrm{X}$ & & & $\mathrm{X}$ \\
\hline Entrepreneurial skills/ Creativity & $\mathrm{X}$ & & $\mathrm{X}$ & \\
\hline Strategic planning & $\mathrm{X}$ & & $\mathrm{X}$ & \\
\hline Positive relationship with media & $\mathrm{X}$ & $\mathrm{X}$ & & \\
\hline Civility & $\mathrm{X}$ & & & $\mathrm{X}$ \\
\hline Enjoyment role, high motivation levels & $\mathrm{X}$ & & & \\
\hline Personal investment of time and money & $\mathrm{X}$ & & & \\
\hline Altruism (motivated by public good) & $\mathrm{X}$ & & & \\
\hline Collaborative approach & $\mathrm{X}$ & & & \\
\hline High Community Involvement & $\mathrm{X}$ & & & \\
\hline Forging friendships & $\mathrm{X}$ & & & \\
\hline Perseverance/stick-ability & $\mathrm{X}$ & & & \\
\hline
\end{tabular}


Now that I have presented several assessments of Geddes' professional and leadership practices and summarised the themes that emerged in the above table, the next chapter will compare this data, on current leadership practice, with the leadership theories set out in the literature review and discuss a number of issues that fall out of this analysis. 


\section{Chapter Three}

\section{Comparing Theory and Practice}

In the last chapter, the research data drawn from interviews with Jim Geddes and his stakeholders, funders and staff was analysed and a number of key themes emerged. This chapter compares Geddes' practice to the leadership theories set out in the introduction and examines where the theory and practice converge and diverge. In the interviews, Geddes' distilled his leadership down to an ability to see and realise opportunities. He pointed to establishing several sustainable facilities and attributed this to selling ideas, generating community buy in and having a trusting rapport with key funding agencies. This summary is remarkably similar to Davies summary that a museum leader:

Produces a clear vision and focuses activities on achieving it. Ensures adequate funding. Is able to communicate. Has professional credibility. ${ }^{1}$

However Geddes' summary does not articulate the final elements of Davies' summary that a museum leader also 'establishes policies, goals and strategies and understands strategic issues'.2 During our interviews, Geddes gave little weight to managerial considerations; indeed, he professed 'not to be a leader in that respect'. He was also critical of a museum director he perceived as heavily favouring the managerial aspects of the role. This is not to say that Geddes' does not plan, he just does it in a way that maintains a high degree of independence and flexibility. I would argue, based on working in Geddes' Department and my discussions with him that Geddes frames all 'big picture' planning within the general ambit of the Gore District Council's annual and LTCCP plans retaining a large measure of discretion on how these overarching goals are achieved. He then arrives at more detailed plans by formulating a framework which he then refines via a process of consulting with senior Council management, the applicable Incorporated Society or Charitable Trust and key funders. Geddes communicates the specifics via the same networks and local media. Several stakeholders commented on Geddes understanding of strategic issues. Ian Tulloch ${ }^{3}$ observed that Geddes was financially astute and understood how to achieve his

\footnotetext{
${ }^{1}$ S.W Davies, "Visionary Leadership and Missionary Zeal," in Museum Management and Marketing, ed. Richard Sandell and Robert R. Janes, Leicester Reader in Museum Studies (Oxford: Routledge, 2007), 264.

${ }^{2}$ Ibid.

${ }^{3}$ A former Mayor of the Gore District and prominent South Island businessman.
} 
objectives through long term strategies. ${ }^{4}$ Realising the projects set out in chapter one by necessity involves goal setting and strategic planning. The evidence suggests that Geddes' interests and motivation lie more in the macro than the micro aspects of his role. During a work conversation, Geddes once asked me how you could plan for John Money's gift, to make the point that adhering to rigid preconceived plans or locally based collection policies would have stymied what has become a major part of the Gallery's identity.

Geddes professed not to understand leadership and said that he has never been a conscious leader. His colleague, Stephanie Herring, also felt that he was not a conscious leader. An upshot of this is that Geddes did not articulate leadership in abstract or academic terms and was much more comfortable talking about his projects. This asks the question of whether Geddes is a leader or simply a capable individual who has worked hard to develop several local cultural facilities? I intend to test this question against several of the leadership theories identified in the Introduction.

Suchy's work on leading with passion, sets out four parts to a museum leader's role. The first is 'representing the museum's story to audiences guided by personal passion'. Over the course of our interviews Geddes related his passion for presenting contemporary art and fresh, vibrant experiences to local audiences. He also spoke of wanting to develop facilities that celebrate Eastern Southland and encourage the development of work relating to it. These passions help explain how a contemporary art gallery and an art studio/residency comfortably sit alongside local history museums. Mayor Hicks referred to Geddes' passion for his work and like Prendergast noted surprise that he is able to communicate this passion in a relaxed laid back way. Geddes is clearly able to represent his Museums' stories [to use Suchy's expression] in an accessible and non-threatening way. All of the interviewees referred to Geddes' sense of passion for Eastern Southland and how this is expressed in his Museums. Cobley noted this emphasis on a regional point of difference as do the other magazine articles referred to at the end of chapter one. ${ }^{5}$ Part of the appeal of the Gallery and Museums is their somewhat unlikely location in a small rural service town. New Zealand's rural towns are not renowned for their cultural offerings, so those that do

\footnotetext{
${ }^{4}$ Larson, "The Fine Art of Gore," 101.

${ }^{5}$ Cobley, "Sex, booze and museums: a heady cocktail in Gore," 18.
} 
this well, tend to stand out. Part of Geddes' formula is that he surprises external audiences with the content of his Museums and as Hicks and Herring both note, he instils a sense of pride in place for local audiences. Here is the tie in with his mentor Fleur Sullivan who Geddes observed, 'realised the only way to grow her local clientele was for visitors to say how good it was'. ${ }^{6}$ Suchy equates passion with energy and heart. Geddes effectively restated this formula in his 1988 annual report when he put the Gallery's early success down to energy, innovation, dedication and enthusiasm. Examples of this passion abound in chapters one and two. For instance Geddes' level of drive bears no correlation to the low remuneration he received between 1986 and 1996 and his willingness to inject his own money at key junctures in his career also evidences a strong degree of passion and personal commitment. As Geddes put it he has a 'stake on a whole lot of levels'.

Suchy's second criterion is that museum leaders create contexts where others (staff and volunteers) can give their best to each other and to visitors. For most of his career, Geddes has worked alone and he clearly values this independence. Geddes supervises four staff at the Gallery and Museum. The Gore Information Centre operates as a separate team with a manager who reports to Geddes. He does not enlist volunteers for professional tasks, but is happy for Museum staff to do so at their discretion. ${ }^{8}$ Herring considers that Geddes takes his time to employ capable people, trusts them with a high level of autonomy and expects high standards. She initially found this autonomy disconcerting but acknowledged the onus it created to produce high quality work. It is worth noting that Herring was invited to apply for her job and then progressed from a fixed term contract to a permanent position, which suggests an element of pre-screening for both skills and compatibility. Herring described Geddes as a 'hands off' but approachable manager. From my observation, I have seen that Geddes outlines the results he wants to achieve and then relies on trust and the controls identified by Herring to manage his team. This approach is consistent with his view that micro control is corrosive; conveniently it also frees up his time. Herring's evidence suggests that Geddes creates a context where staff can give their best. I note he does this without formal team meetings or monitoring performance targets other than as part of staff's annual appraisals. The small size of Geddes' team,

\footnotetext{
${ }^{6}$ Geddes, interview.

${ }^{7}$ Ibid.

${ }^{8}$ As far as I am aware there is no formal policy for this, it is worked out on a case by case basis.
} 
along with the resulting opportunity for regular discussion and high expectations are the most likely explanations for why this informal model seems to work.

Suchy's third criterion is that museum leaders act as (ethical) entrepreneurs and shaping opportunities into viable economic outcomes to ensure their museum's future. John Prendergast, the CEO of the Community Trust of Southland referred to Geddes' ability to 'marry up culture with commerce', , citing the Hokonui Moonshine Museum and associated merchandising, the distillery project and the integration of local businesses into the Southern Odyssey Trail. Geddes identified one of his major challenges as ensuring the sustainability of his projects. He confirmed this concern was behind the purchase of the distillery. In terms of ethics, I note that Geddes' lent to the Hokonui Moonshine Trust a \$150,000 inheritance he received from his mother (for ten years on an interest free basis) to enable this Trust to purchase the business. He could have purchased it himself or set up a joint venture with this Trust. The fact that he did not advance his self-interest points to a very ethical approach. My analysis is that Geddes has had to be entrepreneurial, because of a lack of capital and operational funding. A strong sense of 'necessity being the mother of invention' emerges from the research. Part of the reason for this is because the Gore District Council has never had to assume full responsibility for the provision of cultural services in Eastern Southland. In order to maintain independence, Geddes has resolutely followed a model where the various collections and the facilities that house them remain in the public domain via an umbrella of the Incorporated Societies and Charitable Trusts, which limits the Council's role to funding of management services and (partial) assistance with operating costs. This model has and continues to place a heavy onus on Geddes to secure third party funding for both capital development and operating costs. It also explains the necessity for strong partnerships with the regional funding agencies. The fact that the Gallery maintains a strong exhibitions and performance programme is substantially attributable to an endowment from $\mathrm{Dr}$ Money. The income from the sale of Hokonui Moonshine subsidises the Moonshine and Historical Museums but this is insufficient to fund a dynamic public programme. Independence clearly has a cost. This in turn has lead Geddes to devise creative funding strategies. In this context one of my supervisors asked whether Geddes

\footnotetext{
${ }^{9}$ John Prendergast, September 26, 2011.
} 
attended the Strategic Leadership Programme ${ }^{10}$ which was jointly run by Te Papa's National Services Te Paerangi and Victoria University of Wellington between 2001 and 2006. The answer is no. Geddes indicated that this was not due to a lack of interest but as a sole practitioner managing several projects he did not feel that he could devote the time. Geddes is clearly not the product of conventional management and leadership training. Working alone and then with a small team has necessitated that Geddes' work directly with his community in a 'sink or swim' way. If he did not exhibit the attributes and develop the skill sets identified in chapters one and two, he simply would not have attracted the degree of community and stakeholder support required to establish and maintain his various projects. Geddes presents as an instinctive leader; it would be interesting to ponder what he would absorb from, or add to, the critically reflexive museum leadership programmes.

Suchy's final leadership criterion is that museum leaders nurture relationships of trust with key museum stakeholders for long term sustainability. All of the interviewees cited this as one of Geddes' key strengths. Geddes expressed it as 'generating a healthy degree of community buy-in and a trusting rapport with key funding agencies'. ${ }^{11}$ He sees himself as being able to 'bring partners on board and give them the confidence to be involved and stay on board'. ${ }^{12}$ When preparing his role and network diagram, Geddes said he derived the most satisfaction from working with community stakeholders and described the community sections as his 'support networks'. ${ }^{13}$ Geddes' observation that many of his relationships with stakeholders evolve into friendships and that this generally enriches and strengthens the networks fits well with Suchy's fourth criteria. Hicks reported that Geddes likes to be 'very engaged with stakeholders ${ }^{14}$ and puts this down to a relaxed non threatening style, an ability to clearly communicate the benefits of a project and a willingness to work with other organisations to achieve mutual aims. This sense of reciprocity emerges out of the data as a key theme. Geddes gained John Money's trust by taking the initiative and flying to Baltimore (at his own cost) to catalogue Money's collection and then offering to broker it back in New Zealand. This gave Money the confidence to offer his Collection to the Gallery. Prendergast, the CEO of the Community Trust of

\footnotetext{
${ }^{10}$ Called He Kāhui Kākākura

${ }^{11}$ Geddes, interview.

12 Ibid.

${ }^{13}$ Jim Geddes, October 6, 2011.

${ }^{14}$ Tracy Hicks, September 15, 2011.
} 
Southland described Geddes' dealings with the Community Trust in terms of an 'ongoing partnership ${ }^{15}$ characterised by high degrees of goodwill. He attributed this to interesting projects, realistic funding requests, good communication and a track record of bringing in projects within budget. Consistency and professionalism emerge here as the agent of trust. Herring reported a high level of trust in her working relationship with Geddes and felt that trust also underpins his relationships with private and public funders, with Geddes trusting funders for support and funders trusting him to provide a vision that makes Gore attractive for others.

I now intend to consider Geddes' practice in term of the personal skills and attributes identified by Suchy. The project driven nature of Geddes practice involves a strong element of intentionality. Creativity and problem-solving also emerge out of the data, in terms of Geddes' fund raising abilities, his vision for the fused Heritage Centre model and in resolving the complexities of the John Money project. The commercial distillery project is also further evidence of a strong creative streak. Geddes reports that he relies on 'his intuition a good deal of the time' but shifts to a more analytical and consultative approach when making major decisions. No examples of Suchy's constructive discontent emerged out of the data. Geddes reported that he avoids confrontation preferring to step back and manoeuvre. This may be constructive but I get the sense that this manoeuvring is more uni than bi-lateral. While working in the Department, I have noticed that Geddes is very careful not to express negativity or personal judgment in order to avoid potential conflicts. A strong element of commitment and resilience also emerged, for instance Geddes is proud of the fact that he has been able to 'stick it out when any normal employee would probably have walked away'. ${ }^{16} \mathrm{He}$ attributed this to a desire to deliver on projects that he has encouraged people to invest in and on wanting to ensure sustainability. Establishing the departmental structure seems to have been a key juncture for Geddes, in that it laid a more sustainable platform, providing a reasonable salary for the first time and funded custodial staff, which allowed Geddes to take holidays. The fact that he had foregone holidays confirms a high degree of commitment.

\footnotetext{
${ }^{15}$ Prendergast, interview.

${ }^{16}$ Geddes, interview.
} 
Geddes clearly has the ability to create and maintain a supportive network.

Cultivating and sustaining these relationships motivates Geddes as does the wide variety of his work, observing that he is "nourished by the energy" ${ }^{17}$ of this. All of the interviewees referred to high levels of trust in their dealings with Geddes, which points to him operating within what Suchy calls a trust radius (trusting others until there is a reason not to). In answer to my above question, Geddes' practice fits well within Suchy's model and while he might not be a conscious leader, he nevertheless operates as an effective leader with strengths in stakeholder relationships and creative problem solving.

I now turn to the Transformative Leadership models discussed in the Introduction. Geddes' practice clearly fits much more squarely with transformative, rather than transactional, leadership models, relying more on idealised influence (trust, loyalty and respect in relationships) than appeals to self-interest and contingent reward. The Multifactor Leadership Questionnaire (MLQ) tests for three main elements. The first of these is inspirational and visionary leadership. The research data includes examples of Geddes developing a vision, engendering pride, respect and trust plus creating higher expectations. I have already considered the first four of these elements. I found evidence of Geddes creating higher expectations in his early insistence on establishing a Public Art Gallery rather than a local Art Centre ${ }^{18}$ and in Herring's observation that he expects high standards of his staff. Hicks also noted that Geddes 'exceeds expectations'. ${ }^{19}$ In terms of modelling appropriate behaviour, both Hicks and Prendergast described Geddes as understated and laidback; being generally admired traits. Prendergast also referred to Geddes' modesty, consistency and genuine approach. Herring noted Geddes' accessibility, referring to his open office in the foyer of the Gallery. These factors, coupled with Geddes' emphasis on civility, all point to him modelling appropriate leadership behaviour.

The second main element of the MLQ model investigates whether leaders intellectually stimulate followers with new ideas and approaches. Early in his career Geddes referred to a goal of wanting to expose the viewing public to fresh, new, vibrant experiences. The Gallery meets this goal with its revolving exhibition and

\footnotetext{
${ }^{17}$ Ibid.

${ }^{18}$ Where artists or art groups rent Gallery space

${ }^{19}$ Hicks, interview.
} 
performance programme. As Prendergast noted, so too does Geddes' continual generation of interesting projects. My assessment is that Geddes' emphasis is on providing intellectual interest to his community via the content of his facilities and that he tries not to inject himself unnecessarily into that exchange. The data from the interview with Herring suggests that Geddes leaves his staff to motivate themselves and largely develop their own approaches.

The third main element of the MLQ model is concerned with Individualised Consideration and Development Exchange. Hicks identified a practical example of individualised consideration and development exchange in Geddes' relationship with the Mataura Licensing Trust when Hicks outlined how Geddes has helped the Licensing Trust adopt a stronger cultural focus. The exchange element is evident in Hick's summary of Geddes' role in the Licensing Trust's Thomas Green café project. Geddes' assistance to Dr Money is another example.

Concepts of authenticity and leadership with a higher purpose are closely linked to the above precepts of transformative leadership. Authentic leaders tend not to be motivated by power, seek to persuade by the merit and relevance of their ideas and aim for altruistic goals. Greenleaf concluded that true leadership 'emerges from those whose primary motivation is a deep desire to help others' ${ }^{20}$ The data suggests that Geddes is not motivated by power or control. He thinks micro control is corrosive and he remains open to outside influences in order to refine his overall vision. He stated a preference for a collaborative approach using the analogy of a theatre director to describe his role. Within this analogy he referred to notions of oversight and orchestration of a somewhat fluid script. The funders of Geddes' projects can only have been persuaded by the merit and relevance of his ideas. During our interviews Geddes referred to a sense that he was working for the right reasons, that is to say, for the ultimate benefit of the community and something that was going to be permanently here and of value to the District, rather than of value only to him. It is safe to categorise these goals as altruistic and I conclude that the data points to Geddes adopting and practising the aims of authentic leadership and leadership with a higher purpose.

\footnotetext{
${ }^{20}$ Robert K. Greenleaf et al., The servant-leader within: a transformative path (Paulist Press, 2003), 15.
} 
The Engaging Transformative Leadership Model (The Engaging TLQ model) anticipates that a leader will progressively engage with individuals, the leader's organisation and its stakeholders. Geddes' concentric role and network diagram bears strong similarities with this model. His description of the middle rings ( 3 to 6 ) as being his 'community' and 'support networks' convey a high sense of personal engagement with his community. This high sense of personal connection is also evident in Geddes' comment: 'when you have bones buried in the Mataura Valley you take a special interest in the place'. ${ }^{21}$ This community connection drives Geddes' motivation to work outside the 'safety net' of his core duties and 'explore and develop wider networks'. ${ }^{22}$ Again engagement with place and community emerges as a key part of Geddes' practice, both in terms of how he views his role (Yukl's first cognitive and motivational level of leadership) ${ }^{23}$ and how he approaches his work (Yukl's wider level of organisational leadership as a process within a larger system) ${ }^{24}$

Other leadership models discussed in the Introduction include the concept of multidirectional leadership ${ }^{25}$ which relaxes notions of leader and follower and looks at parties in terms of active partnerships seeking common purposes. This holds up well in the case of Geddes' relationship with the Community Trust of Southland, one of Geddes' key funders. The Community Trust of Southland expresses its vision in terms of leadership and collaboration:

The Community Trust of Southland, by showing strong leadership and in collaboration with the community, will play a significant role in achieving the region's shared vision of a creative, thriving, vibrant, healthy, safe, prosperous and sustainable community. ${ }^{26}$

Prendergast's reference to the Trust's dealings with Geddes evolving into an on-going partnership strikes me as an expression of this concept of multidirectional leadership, with the Trust and Geddes working toward common purposes.

\footnotetext{
${ }^{21}$ Geddes, interview.

22 Ibid.

${ }^{23}$ Gary A. Yukl, Leadership in Organizations, 6th ed. (New Jersey: Pearson, Prentice Hall, 2006), 1517.

${ }^{24}$ Ibid.

${ }^{25}$ Brad Jackson and Ken W. Parry, A Very Short, Fairly Interesting and Reasonably Cheap Book about Studying Leadership (London: SAGE Publications Limited, 2008), 15.

${ }^{26}$ http://www.ctos.org.nz/index.php?pageLoad=8
} 
My research did not present any evidence that Geddes uses Appreciative Inquiry to work with his team to identify the positive qualities of the Department and use this to inform change and make improvements. Whitney, Trosten-Bloom and Rader define Appreciative Leadership as "the relational capacity to mobilize creative potential and turn it into positive power, to set in motion positive ripples of confidence, energy, enthusiasm and performance' ${ }^{27}$ There is evidence that Geddes does this on a personal level but I found no evidence that he engages with his team in such a process. In this regard, I would argue that Geddes is still operating as a capable individual and is perhaps missing an opportunity to develop and share leadership within his Department and assist with succession planning. This is an instance where familiarity with contemporary leadership theory could assist Geddes.

Complexity theory posits that an organisation is a living system with a large number of independent agents who adapt and effect change through dynamic interaction. ${ }^{28}$ Geddes' role and network diagram comprises a large number of independent people and groups (agents) and his observation that the rings are fluid and feed into and out of one another suggests that he sees them as being in dynamic interaction. But what of Pascale, Millemann and Gioja's findings that complex adaptive systems favour a decentralised structure ${ }^{29}$ Geddes role and network diagram does not depict a decentralised structure, on the contrary it places Geddes at the core with radiating networks. This however may be putting too much emphasis on the shape of his diagram, which was a response to my request for a depiction of his roles and associated networks. Complexity Theory suggests that a leader functions as a catalyst, collaborator or facilitator and that leadership is created through interaction with others that is continually constructed' ${ }^{30}$ The following elements of the research align with this view. First Geddes' comment that he relishes 'the freedom to re-invent things and to be able to respond to community needs'. Second we note his observation about the fluidity of his networks. Thirdly, we are reminded of Helen Clark's remark when opening the John Money Wing that the project was an art chain reaction (with Geddes

\footnotetext{
${ }^{27}$ Diana Whitney, Amanda Trosten-Bloom, and Kae Rader, Appreciative Leadership: Focus on What Works to Drive Winning Performance and Build a Thriving Organization (McGraw-Hill Professional, 2010), 29.

${ }^{28}$ Richard T. Pascale, Mark Millemann, and Linda Gioja, Surfing the Edge of Chaos: The Laws of Nature and the New Laws of Business (Three Rivers Press, 2001), 127.

${ }^{29}$ Ibid, 152.

${ }^{30}$ Nanette Blandin, "Leading at the Edge of Chaos," in Transforming Public Leadership for the 21st Century, Transformative Trends in Governance and Democracy (New York: M.E. Sharpe, Inc, 2007), 147.
} 
as the catalyst). Fourthly, there is Geddes' view that his role is analogous to a theatre director. Fifth, there is his comment that his successes have been a 'happy collision of opportunities, the result of the personalities and trust that has evolved'. In addition there is his remark that leadership requires 'a loose hold of the reins so that other influences can help refine the big picture'. And finally I also point to Cobley's observation that 'the community that supports the Eastern Southland Gallery and other museum enterprises represents a complex overlay of local, national and international individuals and organisations, ${ }^{31}$

I now turn to test the application of complexity theory by considering Blandin's analysis of the key attributes she sees at play in complexity-based leadership. Several of Blandin's elements (zeal, communication, collaboration, persistence, resilience, agility, adaption, authenticity and emotional maturity) correspond with Suchy's attributes and need not be revisited here. Blandin theorises that leaders in complex systems rely heavily on process (such as communication and conflict resolution) and that their control over results is not causal and is often non-linear. It strikes me that Geddes' project management is causal and linear but that the genesis of many of his 'opportunities' is much less so. The major gifts of the John Money Collection and Muka Studio's print making equipment were the result of communication, actively helping the donors and seeing a local context for their gifts. Is this a process? I would prefer to call it a practice, a mode of operating and interacting with others that sparks a series of positive events. Here I adopt McCarthy's definition of practice as a combination of action, regular activity, training and work. ${ }^{32}$ Drawing on anthropological theories of culture as a way of doing something and the emphasis in the educational field on critically reflective practice, $\mathrm{McC}$ arthy challenges museum studies researchers to take the study of practice seriously and 'ground its analysis in the day to day activities' of museum professionals. ${ }^{33}$

A key part of Geddes' practice has been the ability to trigger these opportunities. Perhaps this fits better with Blandin's agility and adaption (and Suchy's entrepreneurial) elements of leadership. Similarly Geddes' practice does appear to involve a lot of conflict resolution; my findings suggest he minimises conflict by

\footnotetext{
${ }^{31}$ Cobley, "Sex, booze and museums: a heady cocktail in Gore," 20.

${ }^{32}$ Conal McCarthy, Museums and Maori: Heritage Professionals, Indigenous Collections, Current Practice. (Wellington: Te Papa Press, 2011), 18.

${ }^{33}$ Ibid, 19-20 .
} 
skirting it. The result here is therefore an uneven alignment with Blandin's process orientation criteria. What of Blandin's boundary crossing element? There is limited evidence of this in the permeable relationship between the Gallery and the social history Museums. These organisations share resources in order to foster strong links between art and local heritage. Secondly, there is Geddes' willingness, as Prendergast expressed it, to 'marry up culture with commerce, ${ }^{34}$. Embracing John Money's internationally focused art collection also moved the Gallery from a strictly New Zealand focus but it is fairer to categorise this as an instance of pushing a boundary rather than crossing it. So while there is limited evidence of Geddes' leadership crossing boundaries there is evidence of a readiness to 'keep boundaries fluid, develop connections and promote collaboration'. 35

Blandin's next measure is a commitment to diversity. Complexity theory measures a system's ability to adapt by its exposure to variety and the presence of multiple perspectives. The last twenty eight years have seen high degrees of change and evolution for Gore's Museums. From an organisational perspective Geddes has marshalled several separate Incorporated Societies and Charitable Trusts into working partnerships with the District Council, grown the existing facilities and launched several new ones. Content-wise the Gallery now blends national and international perspectives ${ }^{36}$ and provides variety via its exhibition and performance programmes; however, the local history museums are more local and Pakeha ${ }^{37}$ focused. The prohibition narrative in the Moonshine Museum does, however, present opposing world views within the Pakeha settler community. Geddes' acknowledges a weak bicultural element in the Museums (that is to say an exploration of Māori and Pakeha relations centred on the Treaty of Waitangi) and has commissioned the Otago based Ngāi Tahu historian, Bill Daker, to research local Ngāi Tahu history with a view to interpreting it in the Gore Historical Museum. However this remains a work in progress. On balance, the evidence suggests that Geddes' measures up reasonably well to Blandin's diversity criteria.

\footnotetext{
${ }^{34}$ Prendergast, interview.

${ }^{35}$ Blandin, "Leading at the Edge of Chaos," 148.

${ }^{36}$ John Money's Collection is called "Splendours of Civilisation" with works from Africa, North and South America, Australia and New Zealand.

${ }^{37}$ The Maori name for European New Zealanders.
} 
If commitment to continuous learning is measured against academic criteria, Geddes would not score highly. He undertakes (or commissions) research as and when needed usually in relation to his curatorial work. He keeps abreast of contemporary New Zealand art but does not actively follow contemporary curatorial, leadership or management theory. He unapologetically positions himself on the practice side of the practice/theory continuum.

The degree of convergence between Geddes' practice and contemporary leadership theory is striking for a museum director who professes not to understand leadership. The convergences are such that Geddes clearly emerges as a leader, in terms articulated in the academic work on leadership. Of all the leadership theories, I argue that Geddes' practice most closely resembles the Engaging Transformation Leadership Model with its emphasis on ethical values and a widening series of engagements with individuals, the organisation and stakeholders. I have come to think of Geddes' leadership as organic, in that it has evolved over the course of his career with strong roots in one relatively small community. Geddes' experience and networks have grown in parallel, from a largely project driven base. This provides a large measure of authenticity, as the networks are relationship-based and organised around shared experiences. Friendships have flowed from this and as described in chapters one and two, this has sparked several of Geddes' key projects. Geddes' practice generally echoes the emphasis in contemporary leadership theory on the importance of the emotional and behavioural elements of leadership. The result is strong trust based relationships with stakeholders.

The case study revealed that Geddes did not have a working knowledge of leadership theory and accordingly such knowledge did not inform his practice. As a busy sole practitioner he did not feel that he had the time to attend the recent sector leader development programmes. Having analysed and discussed Geddes' leadership practice through the framework of leadership theory in this chapter, I now bring the study to a close by considering what this means for museum practice and museum studies. 


\section{Conclusion}

\section{Leadership as a Cultural Practice}

I now sum up the case study findings and conclude by considering the significance of this research for museum studies. My research question asks how leadership has manifested itself in Gore's Museums during Geddes' tenure. Geddes' remark about finding a community will and hijacking it ${ }^{1}$ pin points the two essential ingredients in this particular leadership equation, first a community seeking a more positive image and stronger cultural voice and second a similarly motivated individual capable of coordinating and realising that community will. Geddes' expressed his motivation as 'taking a real pride in trying to bring out the best in a place and wanting to do something that will ultimately benefit it'. Frans Baetens expressed the same idea in the context of Geddes' work at the Gallery:

There are a lot of people in the arts world who are directors of a museum in one place, then another, always as part of a career development. But Jim, he comes from Gore and he works for Gore, he's determined to stay local. He's working to bring contemporary art within reach of smaller communities. $^{2}$

A sense of place functions as an 'engagement' mechanism, linking Geddes to stakeholders. Geddes' community development goal also introduces an element of altruism into his leadership, linking in with the principles of leadership with a higher purpose (refer to pages 10-11). These findings support Jones' research that one element of leadership is to be a protector of local culture, to be a 'keeper of the tribe'. This case study confirms Jones' conclusion that leaders can derive legitimacy from remaining local but introducing wider national and international influences. I consider that there is scope for further research on the application of Jones' 'cultural theory' of leadership to museum leadership. The current case study also confirms Shamir's observation that followers [read stakeholders] are co-producers of leadership. ${ }^{3}$ Stakeholders support and fund Geddes' projects because they achieve a common goal of community pride and cultural development. The general success of the projects retains this patronage and also attracts new opportunities and patrons.

\footnotetext{
${ }^{1}$ Jim Geddes, October 6, 2011.

${ }^{2}$ Blundell, "The art of being Gore," New Zealand Listener, November 15, 2003, 23.

${ }^{3}$ Boas Shamir et al., eds., Follower-centered perspectives on leadership: a tribute to the memory of James R. Meindl, Leadership Horizons (United States of America: Information Age Publishing, Inc, 2007).
} 
The ability to engender trust emerged as a second key plank in Geddes' practice. Distilled to its essence, this is the result of Geddes' professional and inter-personal competencies. On a professional level he identifies opportunities, communicates the associated benefits to stakeholders, raises the necessary funds and delivers a professional end result within budget. On an interpersonal level, the interviewees commented positively on Geddes' accessibility, politeness and a relaxed but passionate style. The fact that Geddes is able to consistently apply these leadership elements also generates trust. Geddes' experience and networks have grown in parallel, out of a largely project-driven base. This has resulted in a high degree of authenticity, as the wide networks that Geddes has formed are relationship-based around shared experiences. Friendships have flowed from this and the element of friendship has sparked several of Geddes' key projects. A willingness to lend a hand has paid dividends for Geddes because, as Cobley noted it nurtures a desire to return the favour. ${ }^{4}$ Cobley astutely identified that 'reciprocity is one of the secrets of the successful expansion of the Gallery and the museum enterprises of Gore'.

Commitment and resilience also emerge as strong parts of Geddes' practice. The first decade of Geddes' career was marked by low levels of remuneration and disproportionally high levels of drive. Under resourcing has been a constant issue throughout Geddes' career, to the extent that he has had to inject his own money at key junctures to realise his goals. This commitment is admirable but ultimately unsustainable and has required Geddes to channel his creativity into fund raising, tapping a wide variety of public and private funding sources, which he acknowledged has been and continues to be, a taxing exercise. A conservative observer would promote a lesser number of finished, fully sustainable projects as a safer alternative path, but that is not Geddes' approach. A sense of creativity flows through the case study, first manifesting itself in an artistic and musical way then in curatorship and, as the Arts and Heritage Department has grown, in identifying opportunities and creative thinking to realise and fund these projects. The case study confirms that setting new directions is an important part of leadership.

\footnotetext{
${ }^{4}$ Cobley, "Sex, booze and museums: a heady cocktail in Gore," 20.

${ }^{5}$ Ibid.
} 
I believe that the significance of this study for the academic study of museums lies in the ways in which it expands and refines museum studies by drawing on leadership theory and integrating this with a detailed case study of leadership practice. The research reinforces the notion that successful leadership is really a practice, a mode of operating and interacting with others, and that if consistently applied this cultural practice sparks a series of positive events. The implications of this research for current museum practice are that wider networks, stakeholder engagement and trust will flow from putting into practice, that is enacting or carrying out the emotional, interpersonal, and creative competencies of leadership identified in the literature review. Geddes is a natural leader and though his case suggests that a theoretical knowledge of leadership is not necessary to be a successful museum leader, nevertheless having surveyed the literature and identified a number of ways in which it could have enhanced Geddes' practice, I argue that a theoretical knowledge opens up a wider range of leadership strategies and a more reflective approach. This case study also suggests that a sense of place can function as a mechanism for museum leaders to profitably engage with stakeholders and that returning to work in one's home area provides a set of ready networks that if used creatively, can lead to unexpected opportunities.

In my view, the implications of this research for professional development and training are that museum leaders [both aspiring and established] need to take personal responsibility for establishing mentor relationships as well as understanding and practising leadership skills, regardless of the seniority of their position. Access to a wide range of leadership approaches and resources would encourage a conscious exercise of leadership. The sooner museum professionals are conscious of leadership principles the better, as this will assist with their career direction and professional development. Supporting emerging museum leaders to work in local or district museums could provide considerable development opportunities for the museum, the wider community and the emerging leader. I conclude by offering five recommendations for leadership development in New Zealand's museum sector: 
1. That when appointing staff or when determining career pathways and planning professional development, employers assess whether aspiring and established museum leaders demonstrate the emotional, interpersonal, and creative competencies identified in the literature review and that these factors are given at least equal weighting to technical and managerial competencies.

2. That aspiring museum leaders not discount working in local or district museums as the development opportunities are immense for the organisation, its community and the aspiring leader. The case study confirmed that existing links to one community (of place or of interest) offer a strong foundation to build on. This could be encouraged by incentives such as those offered by the education sector where teachers get an annual payment (currently $\$ 2,500)$ for teaching in hard to staff areas and relocation assistance after teaching for a set period.

3. That in order to develop a more informed understanding of leadership, there is merit in New Zealand's post graduate museum studies courses including a leadership component in their foundation papers. The earlier that museum professionals are aware of the requisite skills, the sooner they can start to practice and develop them.

4. That future museum sector leadership training programmes target emerging as well as established leaders so that the foundations of leadership can be established before individuals take on formal leadership roles. To promote this, annual scholarships could be established for several aspiring museum leaders to attend a cross-discipline, tertiary level leadership development programme.

5. That aspiring and established museum leaders need to keep abreast of contemporary leadership theory, establish mentor relationships and take responsibility for their own personal and professional development. To assist busy regional based practitioners, the sector could form a partnership with a tertiary leadership programme to disseminate a range of approaches to and resources on leadership. This need not be expensive as it would involve collating existing resources. 


\section{Bibliography}

\section{Primary sources}

\section{a) Reports}

Geddes, Jim. Exhibition Officer's Report. Annual Report. Gore: Eastern Southland Gallery, August 2, 1989.

The New Zealand Tourism Research Institute. Museum Leadership Programme Investigation. A report prepared for National Services Te Paerangi. Auckland University of Technology, July 2010.

\section{b) Interviews}

Geddes, Jim, September 19, 2011.

- September 22, 2011.

- September 27, 2011.

- September 29, 2011.

$\longrightarrow$, October 6, 2011.

Herring, Stephanie, September 23, 2011.

Hicks, Tracy, September 15, 2011.

Prendergast, John, September 26, 2011.

\section{Secondary sources}

\section{a) Books and Journal Articles}

Alimo-Metcalfe, Beverly. "Leadership, culture and transformation: building capacity across communities" presented at the NE Leading Improvement for Health and Well-being Programme: Learning event 2, Durham University, April 16, 2010 .

http://www.dur.ac.uk/resources/public.health/nelihwp/NELIHWBPLE2BevAli moMetcalfe.pdf. 
Avolio, B.J., B.M. Bass, and D.I. Jung. "Re-examining the components of transformational and transactional leadership using the multifactor leadership questionnaire.” Journal of Occupational and Organisational Psychology, no. 72 (1999): 441-62.

Bass, Bernard M. Leadership and performance beyond expectations. Free Press, 1985.

Blandin, Nanette. "Leading at the Edge of Chaos." In Transforming Public Leadership for the 21st Century, 138-153. Transformative Trends in Governance and Democracy. New York: M.E. Sharpe, Inc, 2007.

Davies, S.W. "Visionary Leadership and Missionary Zeal." In Museum Management and Marketing, edited by Richard Sandell and Robert R. Janes, 253-271. Leicester Reader in Museum Studies. Oxford: Routledge, 2007.

Dick, Allan. "Gore and More." NZToday, Journeys through our Heartland, February 2008.

Falconer, James. “Accountability in a Complex World.” Emergence 4, no. 4 (2002): 25-38.

Feagin, Joe R., Anthony M. Orum, and Gideon Sjoberg, eds. A Case for the Case Study. Chapel Hill: The University of North Carolina Press, 1991.

Fernando, Mario. Spiritual leadership in the entrepreneurial business: a multifaith study. Edward Elgar Publishing, 2007.

Fry, L.W. "Toward a paradigm of spiritual leadership." Leadership Quarterly 15, no. 5 (2006): 619-722.

Geddes, Jim. "Eastern Southland Gallery - Gore." AGMANZ Journal, no. 19.1 (1988): 9.

Genoways, Hugh H., and Lynne M. Ireland. Museum Administration: an introduction. Lanham: Altamira Press, 2003.

Greenleaf, Robert K., Hamilton Beazley, Julie Beggs, and Larry C. Spears. The servant-leader within: a transformative path. Paulist Press, 2003.

Jackson, Brad. "Getting Respect at the Dowse." In Communication and Organisations: Case Studies in New Zealand and Australia, edited by Theodore Zorn and Deborah Page, 171-177. Auckland: Pearson Prentice Hall, 2007.

Jackson, Brad, and Ken W. Parry. A Very Short, Fairly Interesting and Reasonably Cheap Book about Studying Leadership. London: SAGE Publications Limited, 2008.

A.M. Jones, "The Anthropology of Leadership: Culture and Corporate Leadership in the American South," Leadership 9, no. 1 (2005): 259-278. 
Lewin, Roger, and Birute Regine. The soul at work: listen, respond, let go: embracing complexity science for business success. Simon \& Schuster, 2000.

McCarthy, Conal. Museums and Maori: Heritage Professionals, Indigenous Collections, Current Practice. Wellington: Te Papa Press, 2011.

McMillan, Elizabeth M. Complexity, Organizations and Change. Routledge, 2004.

Pascale, Richard T., Mark Millemann, and Linda Gioja. Surfing the Edge of Chaos: The Laws of Nature and the New Laws of Business. Three Rivers Press, 2001.

Rost, Joseph Clarence. Leadership for the twenty-first century. Westport, Connecticut: Greenwood Publishing Group, 1993.

Sandell, Richard, and Robert Janes. "Complexity and Creativity in Museum Management and Marketing.” In Museum Management and Marketing, edited by Richard Sandell and Robert Janes, 1-15. Leicester Reader in Museum Studies. Oxford: Routledge, 2007.

Sandell, Richard, and Robert R. Janes, eds. Museum Management and Marketing. Leicester Reader in Museum Studies. Oxford: Routledge, 2007.

Shamir, Boas, Rajnandini Pillai, Michelle.C. Bligh, and Mary Uhl-Bien, eds. Follower-centered perspectives on leadership: a tribute to the memory of James R. Meindl. Leadership Horizons. United States of America: Information Age Publishing, Inc, 2007.

Stake, Robert E. The Art of Case Study Research. Thousand Oaks, California: SAGE, 1995.

Suchy, Sherene. "An international study on the director's role in art museum leadership". Doctorate, University of Western Sydney, 1998.

http://arrow.uws.edu.au:8080/vital/access/manager/Repository/uws:517.

Suchy, Sherene. Leading with Passion: Change Management in the 21st-century Museum. California: Altamira Press, 2004.

Whitney, Diana, Amanda Trosten-Bloom, and Kae Rader. Appreciative Leadership: Focus on What Works to Drive Winning Performance and Build a Thriving Organization. McGraw-Hill Professional, 2010.

Yin, Robert K. Case study research: design and methods. Vol. 5. Second. Applied Social Research Methods Series. Thousand Oaks, California: Sage Publications, 1994.

Yukl, Gary A. Leadership in Organizations. 6th ed. New Jersey: Pearson, Prentice Hall, 2006. 


\section{b) Thesis}

Suchy, Sherene. "An international study on the director's role in art museum leadership". Doctorate, University of Western Sydney, 1998.

http://arrow.uws.edu.au:8080/vital/access/manager/Repository/uws:517.

\section{c) Magazine articles}

Bean, Glenys. “Small Town Surprise.” AA Directions, Winter 2008.

Blundell, Sally. "The art of being Gore." New Zealand Listener, November 15, 2003

Dick, Allan. "Gore and More." NZToday, Journeys through our Heartland, February 2008.

Larson, Virginia. "The Fine Art of Gore.” North and South, December 2003.

\section{d) Media Release}

Museums Aotearoa, Media Release, 2008 Individual Achievement Award, April 10, 2008.

e) Speech

Clark, Helen. "Eastern Southland Gallery". Speech presented at the Opening of the John Money Wing, Gore, December 12, 2002. 